\title{
成人男性における䫟関節のX線学的研究
}

顎関節側斜位法抢よび眼窩・下顎枝法による顎関節の分析—

\section{九州雨科大学霜科放射線学講座（指導：大庭 健教授）}

陳昭榮

四体和56仰11月 6 月受付

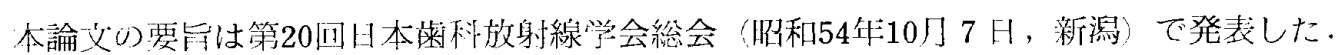

Radiological Study of the Temporomandibular Joint in the Adult Males

- Analysis of radiographs obtained by the oblique lateral

transcranial and orbito-ramus projections

Chaio-Yen, Chen

Department of Dental Radiology (Director : Prof. Takeshi Ohba)

Kyushu Dental College, Kitakyushu, Japan

The temporomandibular joint (TMJ) is a more complex joint than any other joints in the body from the functional and anatomical view point. The diagnosis and treatment of TMJ disorders are also more difficult than for other joints. Consequently, the radiological diagnosis of the TMJ is becoming important. Many radiographic techniques are available for diagnosis of TMJ disorders.

The oblique lateral transcranial projection (OLTP) is the most frequently used technique in diagnosis of TMJ disorders. Since the OLTP reveals only the lateral view of the TMJ, another supplemental projection is necessary to obtain the frontal view of the TMJ. The orbito-ramus projection (ORP) shows the entire lateromedial extent of the articular eminence and the condyle.

There are few radiological studies on the normal TMJ. The purpose of this study is to determine the normal radiographic findings of $\mathrm{TMJ}$ in the adult males. And a comparative study of each radiographic technique is also done in this study.

The OLTP TMJ radiographs were taken with the teeth in maximum intercuspation with the head positioner designed by Ohba et al. (1967). The central X-ray is directed from a point $1.3 \mathrm{~cm}$ anterior to the ear rod of the head positioner. The head position is adjustable by tilting the base boad from $15^{\circ}, 20^{\circ}, 25^{\circ}$, and $30^{\circ}$ in vertical angle to the Frankfort horizontal plane. The ORP TMJ radiographs were taken with the mouth in maximum opening. The central $\mathrm{X}$-ray is directed obliquely to the examining side from a point just through the pupil of the same side. The vertical angle is $30^{\circ}$ from above, and the patient's head is turned horizontally $20^{\circ}$ to the examining side.

The study was done on two hundred adult males having no clinical symptoms and 
signs on the TMJ. The age of the subjects ranged from twenty-three to thirty. Eight hundred radiographs obtained by OLTP were divided into four groups: Group $\mathrm{A} ; 15^{\circ} / 0^{\circ}$ and $20^{\circ} / 10^{\circ}$, Group B; $20^{\circ} / 0^{\circ}$ and $20^{\circ} / 10^{\circ}$, Group C; $25^{\circ} / 0^{\circ}$ and $20^{\circ} / 10^{\circ}$, and Group $\mathrm{D} ; 30^{\circ} / 0^{\circ}$ and $20^{\circ} / 10^{\circ}$. Two hundred and twenty-six radiographs obtained by ORP were analysed radiologically. The results obtained are as follows :

1) By OLTP the condylar position located almost in the center of the glenoid fossa $(75 \%)$. By our projection $\left(20^{\circ} / 10^{\circ}\right)$, the incidence of central condylar position was $84 \%$ and posterior condylar position was two times as compared with the anterior condylar position.

2) For evaluation of the cortex in glenoid fossa, and articular eminence, $20^{\circ} / 0^{\circ}$ and $15^{\circ} / 0^{\circ}$ are to be useful radiographic techniques. The joint space is also clearly projected by $20^{\circ} / 0^{\circ}$ and $15^{\circ} / 0^{\circ}$. The $25^{\circ} / 0^{\circ}$ and $30^{\circ} / 0^{\circ}$ are not suitable techniques for examination of the cortex and joint space.

3 ) The superimposition with the petrous portion, tympanic portion, and the posterior clinoid process to the TMJ structures cannot be avoided by the individual OTLP except the $30^{\circ} / 0^{\circ}$.

4) The condyles in OTLP mostly showed a symmetric shape. Most of condyles revealed an index-finger shape. The next was a sharp-ended shape and then a bulky shape.

$5)$ The shapes of the articular eminence in the OTLP showed mostly a convex type (smooth). The next was a flat type and then a steep type. The majority of the articular eminence showed a symmetric shape.

6) The antero-posterior distance of the right glenoid fossa was longer than that of the left side. The depth of the right glenoid fossa was deeper than that of the left side. The average antero-posterior distance and depth of the glenoid fossa in 400 joints were $18 \mathrm{~mm}$ and $7 \mathrm{~mm}$ respectively.

7) The average joint space in $20^{\circ} / 10^{\circ}$ was $6.0 \mathrm{~mm}$ at the anterior region, $3.6 \mathrm{~mm}$ at the central region and $3.5 \mathrm{~mm}$ at the posterior region. The individual portion of joint space can be expressed by a ratio as $1.7: 1.0: 1.0$ for the anterior, central, and posterior regions.

8 ) In the ORP, there was no great problems, such as the superimposition of the mastoid sinuses, zygomatic process and the articular eminence to the condyle.

9 ) The majority of shapes of condyles in ORP showed a convex (61.5\%), and the next was a round type $(19.9 \%)$ and the third was a flat type. Most of condyles showed a symmetric shape.

10) The shapes of the articular eminence in ORP mostly showed a flat type (45\%), the next was a convex type $(27.4 \%)$, and the third was an irregular type $(27 \%)$. The bilateral symmetry was also seen in the articular eminence. 


\section{緒言}

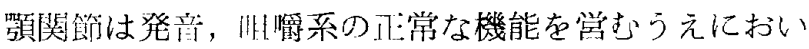

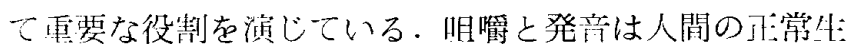
活で最も基本的かつ重要な機能である。そこで，顎関䀶 に们らかの異常が牛ずると, 種々の障贯が起こってく る.

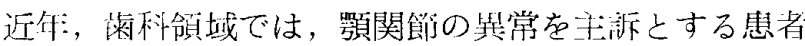
が多くなっている1，顎関節症の原有ならびに治療は基

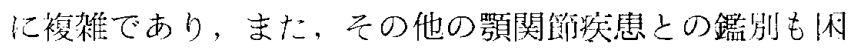
難な場令が多い。

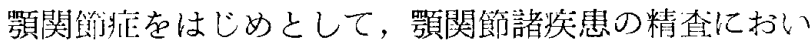
ては，X線検査が重要な役㓶を演じている。顎関䉥のX 線検查法として占くから多くい方法が利用されている

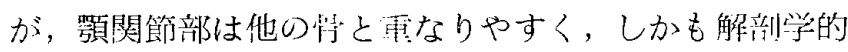
に個体差があり，決定的な顎関钫门摄影法はないといっ ても過言でない。

顎関節は解剖哭的に複杂倠な構造をしているため，多方 响からの灏影が要求される。顎関節の代表的な㨉影法と して，大きく分けて前後方向，側方向および軸方向から の撮影法がある。その恬でも侧方向からの撮影が多用さ れているのが現状である，僛方向からの撮影の代表的な ものとして,侧斜位撮影法 (oblique lateral transcranial projectionがある。侧斜位撮影法は顎関節の側方像し か描花されないという人点があるため，他の撮影法を補 助的に心用しなけ机ばならない。すなおち，前後方们

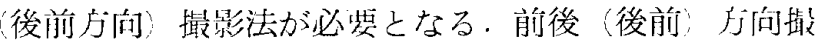

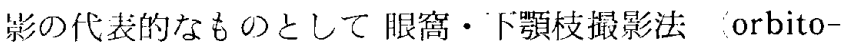
ramus projection がある. 本撮影法は，一顎垟や関節 結節の前後的形態や大きさおよび消の質的変化などり彰 断ができるという卧所を持っている。ところが瀶床的に は, 則斜位撮影法のみが顎関節のX線検查法として利用 されているのが現状である。

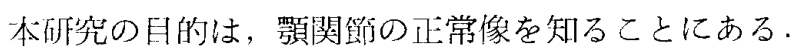
そこで, 正常成人明子を対象として, 側斜位摄影法なら びに眼窝・下顎枝撮影法を行い得られたX線军真の分析

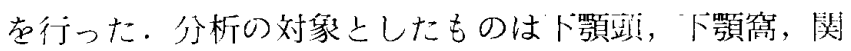

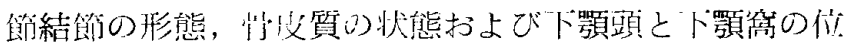
䈯的関係などについてである。また，正常群を対象にし た場合の本学に扔ける規格撮影法と Schüller's 法との 比較検傠も行い，與味ある結果を得たので作せて毁告す 万.

\section{研究対象および方法}

I. 顎関節側斜位撮影法（以下倒斜位撮影と略す.)
A 、頙部周定装犆および撮影装琵

本作究に朋いた撮影法はエレマ・シエナンデル补の竐

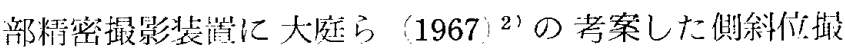

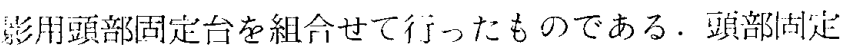
台は角度調整が可能で，基底板には耳桿があり，耳桿で 患者入左有耳孔を固定でき得るようになっている，患者

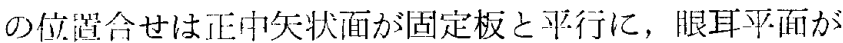
前後的に水平になるように位犆付ける。仙心線は被検 側耳桿の前方 $1.3 \mathrm{~cm}$ の所でフィルム画に対して西直に入 射する。X線の入射角度は顽部基底板の傾斜㑇度で調整 できるようになっている。

B. 撮影条件

撮影条件は管電压 $70 \sim 75 \mathrm{kVp}$ ，管電流 $100 \mathrm{~mA}$ ，焦点 ・フィルム開距離 $85 \mathrm{~cm}$, 撮影時䦐 0.4 0.6秒であり, リスホルム・ブレンデを使用している（格子比は6/1 ・ 使用したX線フィルムは Fuji-RX，フィルムの大きさ

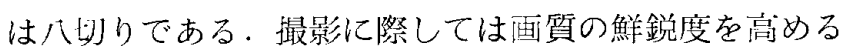
ため僬光円简（Tubus）使用し，照射野は值径 $16 \mathrm{~cm}$ 紋った。

C . 顎関飤撮影に扔けるX線像の再現性について

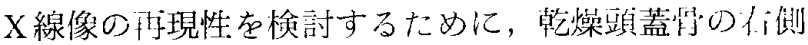
顎関節部周辺にV字型のマークを 3 個貼付しX線撮影を

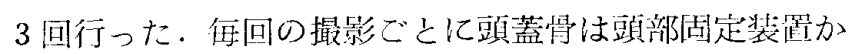
ら取りはずした。3 可の撮影により得られたX線像をえ れぞれトレースし，V字型处齿 A，B，CD3点開の趾！ 離を計测した。計测は $1 / 20 \mathrm{~mm}$ 日盛のノギスで 3 [目行

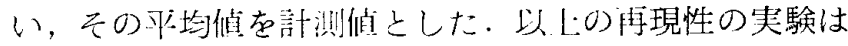
術者2多により行った。

D. 们究対象

佃究対象は正常な咬合を有し，敛関钓抢よびその間辺 に何ら臨床症状を伴わない成人男子 200 名を対象とした。

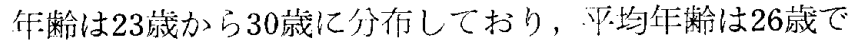
あった。

E. 哌究方法

200名を各種撮影角度门組合せにより4群に分けた。 すなわち，頭部固定板の倾斜解度を上方招よび前方に それぞれ $15^{\circ}$ と $0^{\circ}$ 以下 $15^{\circ} / 0^{\circ}$ と略す， $20^{\circ}$ と $0^{\circ}$ 以卜 $20^{\circ} / 0^{\circ}$ と略子， $25^{\circ}$ と $0^{\circ}$ 以下 $25^{\circ} / 0^{\circ}$ と略す， $30^{\circ}$ と $0^{\circ}$ 以下 $30^{\circ} / 0^{\circ}$ と略すに傾斜させたものと当教空で行って いる $20^{\circ}$ と $10^{\circ}$ (以下 $20^{\circ} / 10^{\circ}$ と略す) の撮影法との比較

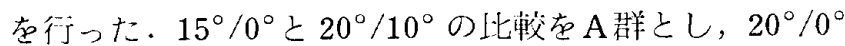
と $20^{\circ} / 10^{\circ}$ の比較を B君羊， $25^{\circ} / 0^{\circ}$ と $20^{\circ} / 10^{\circ}$ の比較を C 群, $30^{\circ} / 0^{\circ}$ と $20^{\circ} / 10^{\circ}$ の比晈をD群とした。各群の力:イ 側を検查の対象とし，咬頭㛣合位にて撮影を行った。撮 
影は 1 名につき左右閉口で 2 種類の撮影を行ったので， 撮影枚数は 4 枚となり，延べ 800 枚のX線写真が得られ た．X線学的に検討する項目は次のとおりである。

1. 側斜位での下顎頭つ位㯰

平田 (1978） ${ }^{3)}$ の分類に従って，図 1 に示すように 3 型に分類した。中央型というのは，“下顎頭はほぼ下箱窩 の中央部に位置するものであり，前方型とは前方部に，

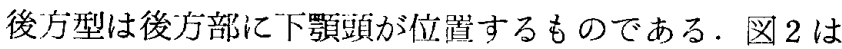
各型つX線写真である。

2. 下顎頭骨皮質の状態

骨皮質の変化の状態を図 3 に示すように，5型に分類 した。 I 型は下顎頭の骨皮質が眀瞭に，しかも連続的に 認められるもの，II型は下顎頭の上方部の骨皮質が断裂 または消失しているもの．型は下堮頭上方部から前方 部にかけてい骨皮質が断裂または消失しているもの，IV 型は下顎頭上方部から後苛部にかけての骨皮質が断裂ま たは消失しているもの，V型は下顎頭全体の罚皮質が断 裂あるいは消失しているもの，図 4 は各型のX線写真で

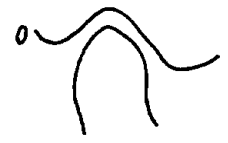

中央型

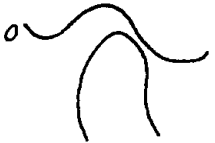

前方型

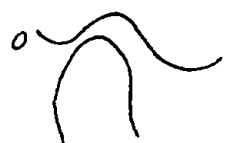

後方型
脳 1 模式的に示した閉口時下顎頭の位置

(側斜位撮影法による)
ある・

3. 下顎窩骨皮質の状態

骨皮質の変化の有無を図 5 に示すように，5型に分類

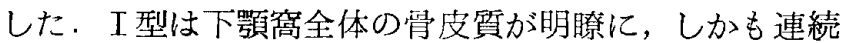
的に認められるもの。Ｉ型は下顎窩中央部の骨皮質が断 裂または消失しているもの，III型は下顎窩中央部から前 方部にかけての骨皮質が断裂または消失しているもの。 IV 型は下顎窩中央部から後方部にかけての骨皮質が断裂 または消失しているもの，V型は下顎窩全体の骨皮質が 断裂または消失しているもの，図 6 は各型のX線写真で 市る。

4. 関節結節骨皮質の状態

骨皮質の変化の有無を図 7 に示すように，5型に分類 した。I型は関節結節全体の骨皮質が明膫に，しかも連

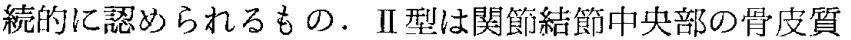
が断裂または消失しているもの，而型は関節結節中央部 から前方部にかけての骨皮質が断裂または消失している もの，IV型は関節結節中央部汃ら後方部にかけての持皮 質が断裂または消失しているもの，V型は関節結節全体 の骨皮質が断裂または消失しているもの，図 8 は各型の X 線写真である。

5. 錐体，鼓窒部およびトルコ鞍の床状乫起など による重なりの有無

錐体による重なりの有無は下顎窩中央部，関節腔隚中 央部および下顎頭についてのみ調べた，鼓室部およびト

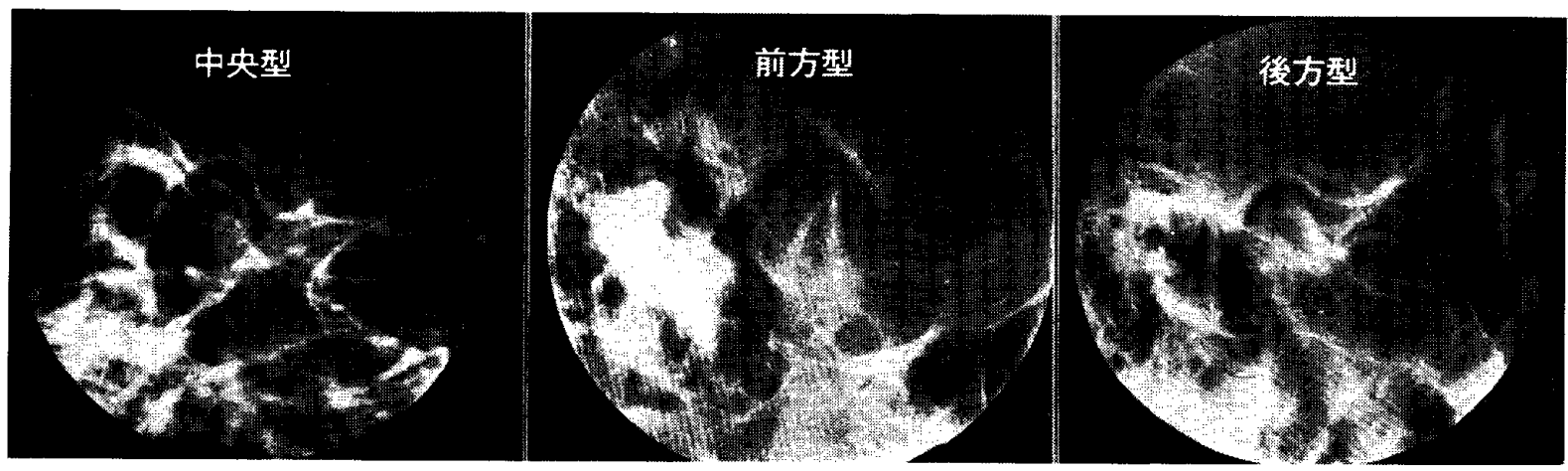

図 2

各種閉口時下顎頭の位犆を示す $\mathrm{X}$ 線写真

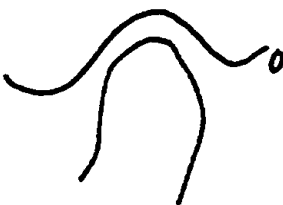

I 型

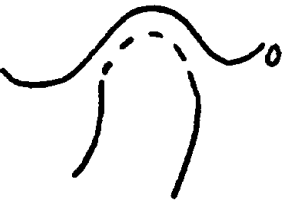

II 型

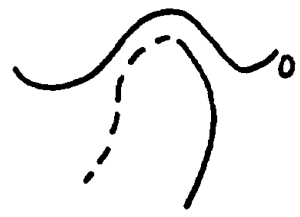

正型

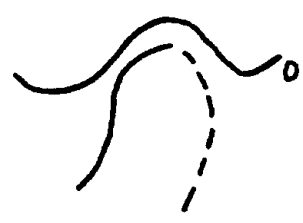

IV 型

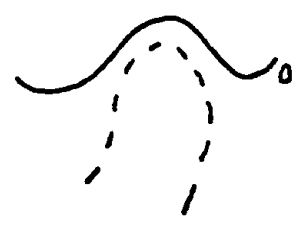

$\mathrm{V}$ 型

应 3

模式的に示した下颚頭骨皮質の状態（側斜位撮影法による） 


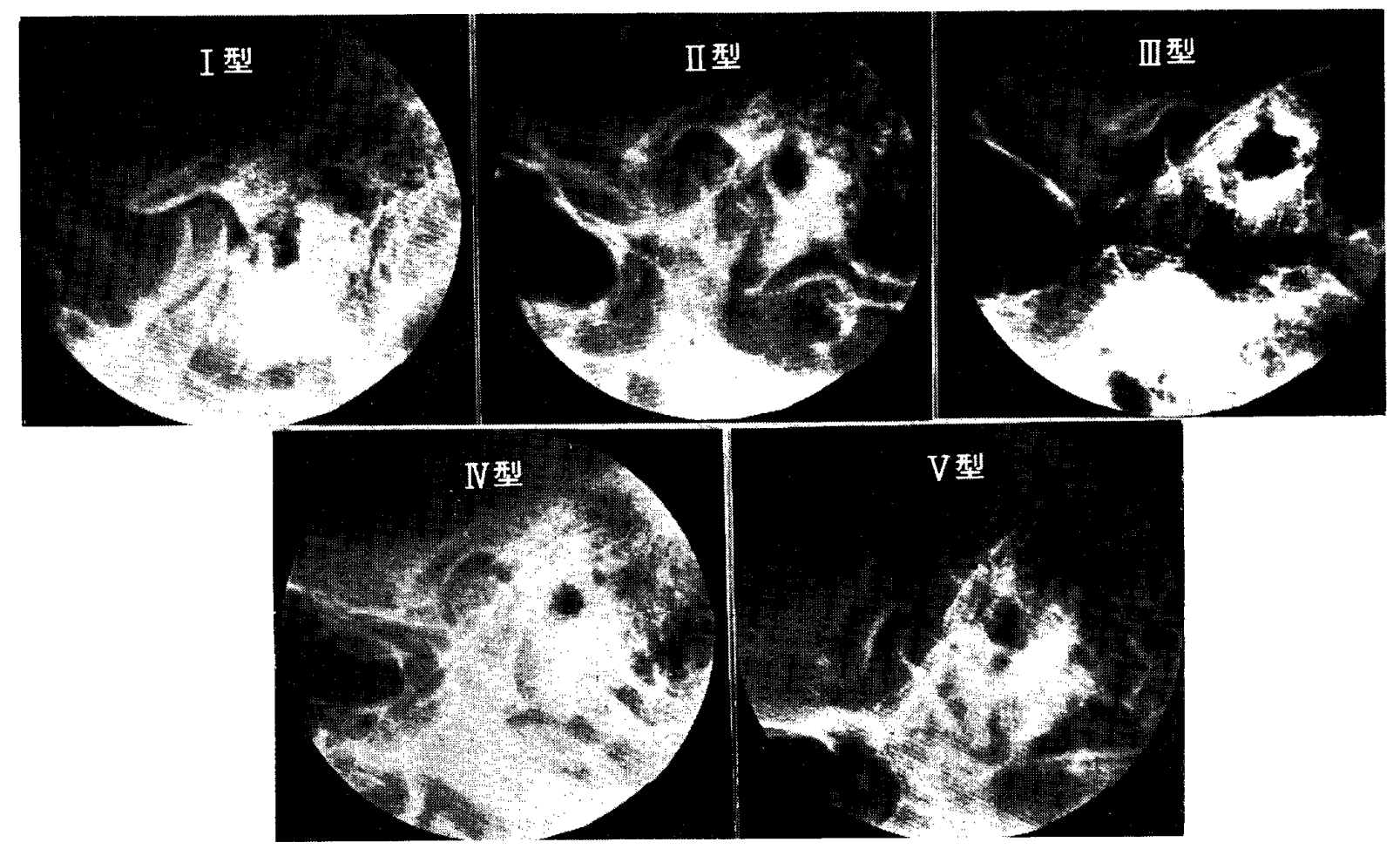

図 4

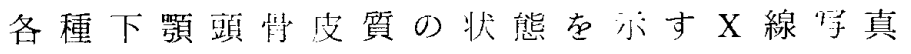

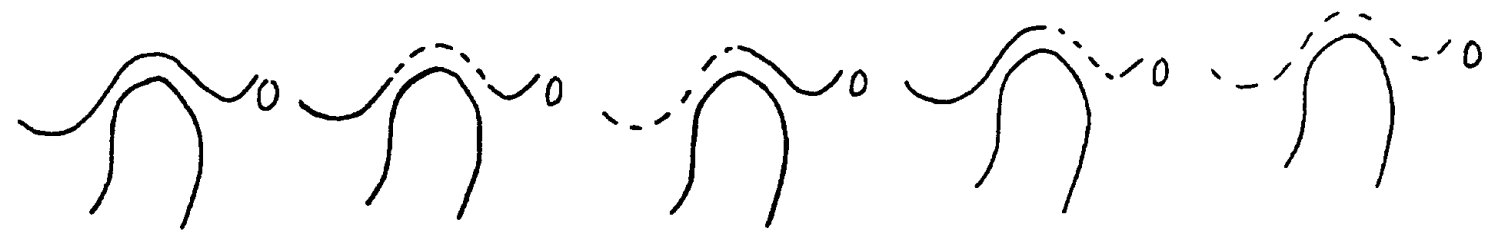

I 型

II 型

III 型

$\mathrm{N}$ 型

$\mathrm{V}$ 型

陇 5

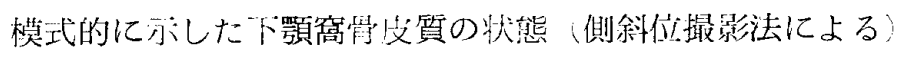

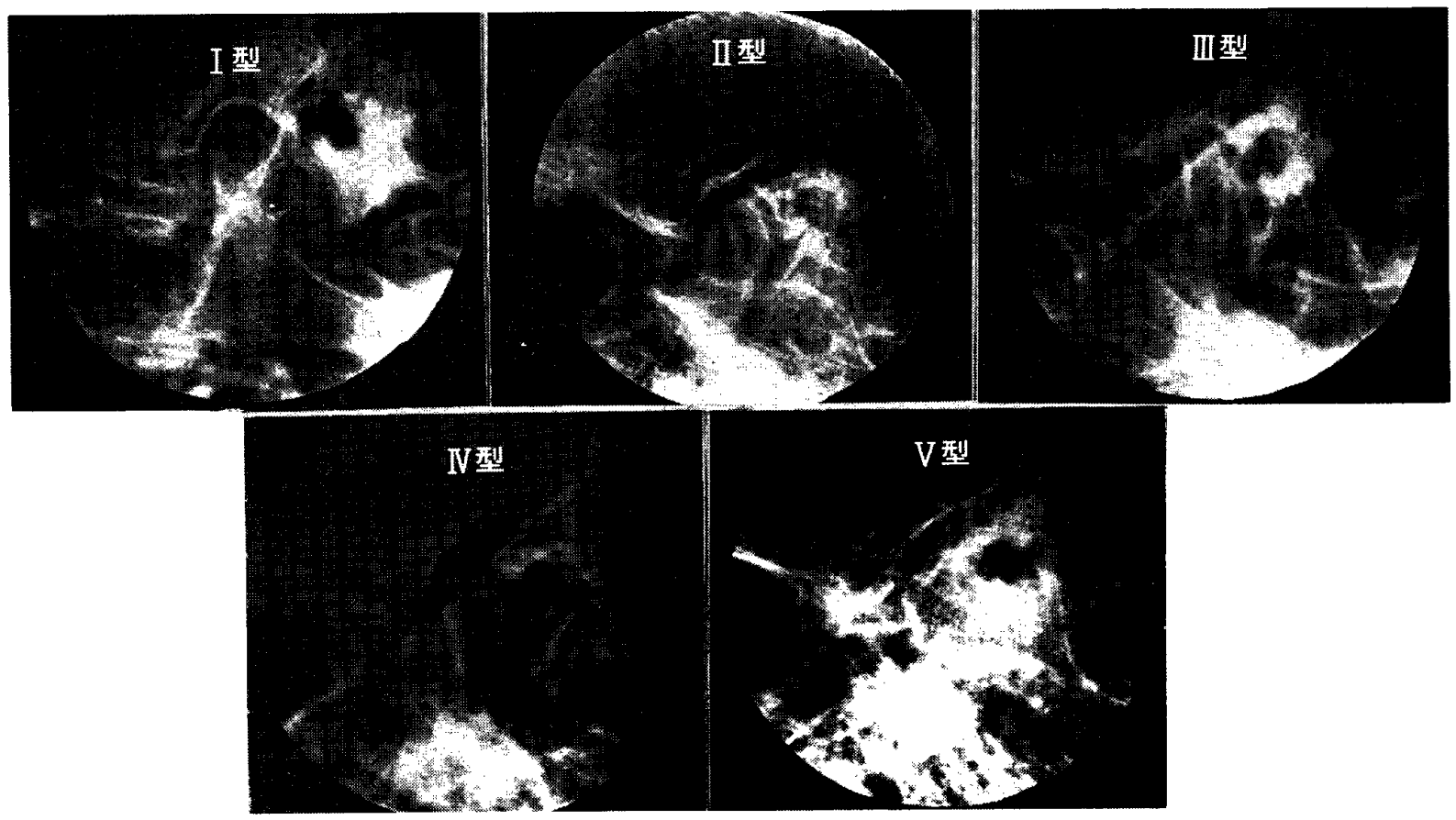

図 6

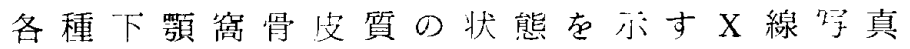




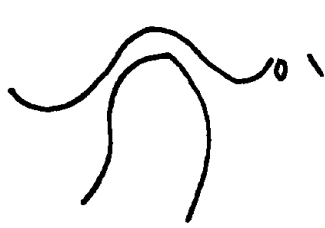

I 型

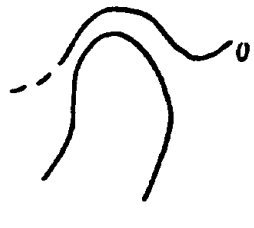

II 型

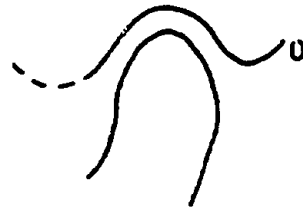

II 型

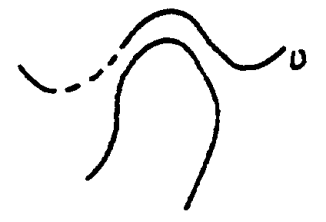

IV 型

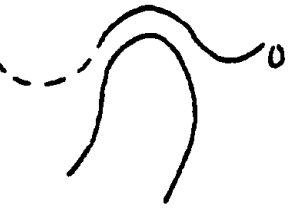

V型

闵 7

模式的に示した関節結節骨皮質の状態（側斜位撮影法による）

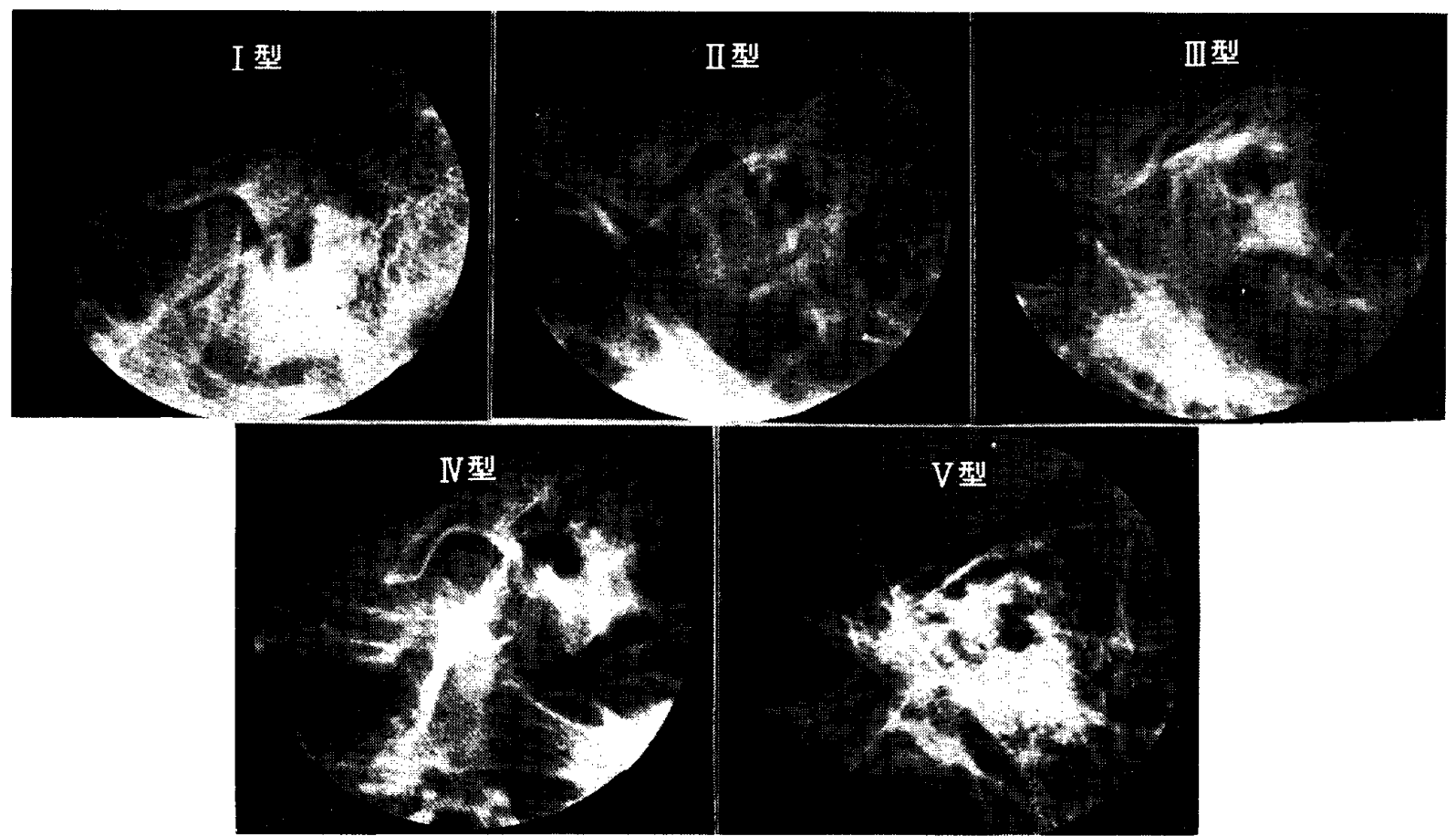

図 8

各種関節結節骨皮質の状態を示すX線写真

ルコ鞍の休状突起との重なりは，それぞれ関節腔陌後方 部および関節腔陌前方部についてのみ調べた，以上の調 査は30例について行った。

\section{6. 関節腔隙の明膫度}

関節腔陌を前方，中央，後方部に分け，それぞれの部 位における明瞭度を調べたＩ型は明瞭に現われている もの，II型はやや明睹に現われているもの． II 型は不明 幚なものとした．以上の調査は30例について行った。

7. 下顎頭の形態分類

高久 $(1961)^{4)}$ の分類に準して, 人示指頭型, 塊型, 尖鋭頭型およびその他の 4 形態に分類した。

8. 関節結節の形態分類

関節結節の形態を図 9 に示すように 3 型に分類した。 I 型は円滑型，II 型は平坦型，III型は急峻型とした。

9. 下顎窩の前後径および高さの計測

下顎窩の前後径と高さの計測は次の方法で行った．関

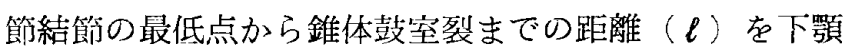

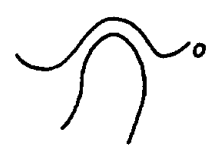

円滑型
平坦型

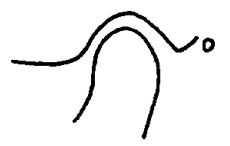

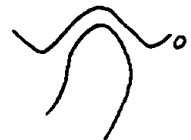

急峻型
図 9 模式的に示した関節結節の形態分類 (側斜位撮影法による)

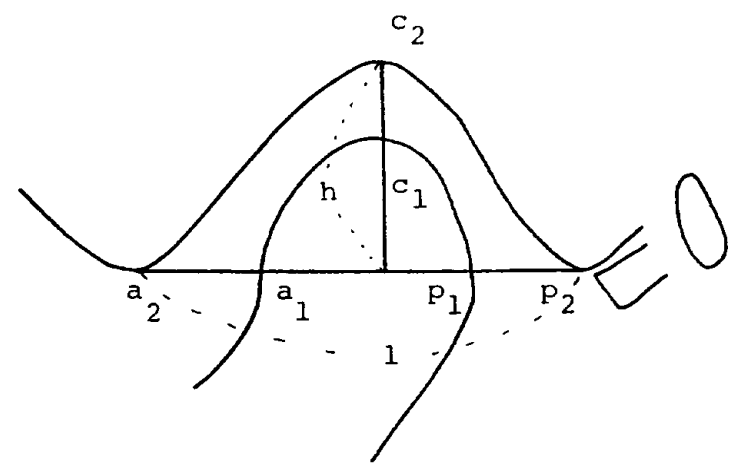

図10 下顎窝前後径, 高さおよび関節腔幅径の計測法 


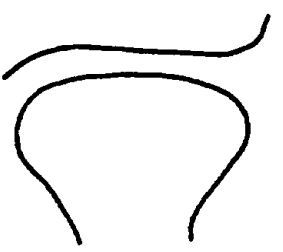

I 型

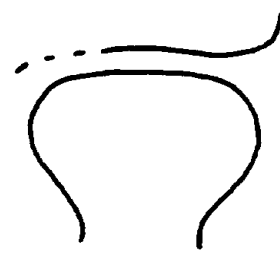

II 型

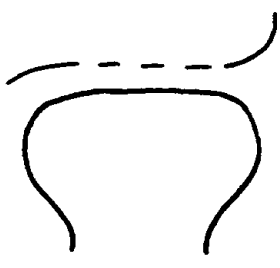

III型

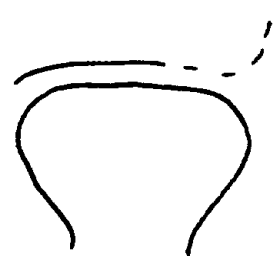

IV 型

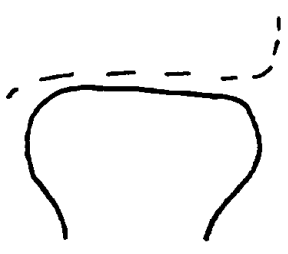

$V$ 型

应11

模式的に示した関節結節骨皮質の状態（眼䈑・下呺枝撮影法による）

㸗の前後径とする，下顎窩の最も高い点から関節結節・ 錐体鼓室裂を結ぶ直線に金線を引き，その交叉した点ま での距離 $(\mathrm{h})$ を下顎窩の高さとする（図10）.

10. 各関節腔幅径の計測

図10に示すように直線 $\ell$ および $\mathrm{h}$ と下顎頭倿した $\mathrm{a}_{1}, \mathrm{c}_{1}, \mathrm{p}_{1}$ ，下䫟窩に接した $\mathrm{a}_{2}, \mathrm{c}_{2}, \mathrm{p}_{2}$ から， $\overline{\mathrm{a}_{1} \mathrm{a}_{2}}$,

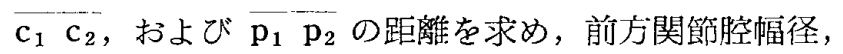
中央関節腔幅径および後方関節腔幅径とする.

9,10の計测 はトレーシング・ペーパー上で精度 $1 / 20 \mathrm{~mm}$ の ギスを用いて行った。計測值は 3 回の計测 值の平均値である.

II . 眼简・下䫟枝撮影法 (以下眼简撮影之略す)

背卧位にて, 顔面の正中矢状面を検側へ $20^{\circ}$ 傾け, orbito-meatal line がフィルム面に垂直になるように頭 部を固定して，中心X線は検側の眼窩を介してフィルム 面に向って $30^{\circ}$ の角度で瞳孔に入射し, 撮影漈しては最 大開口させる．使用フィルムは八切りであり，それを 2 分割し左右側用とする. 撮影条件は，管電圧 $62 \sim 64 \mathrm{kVp}$, 管電流 $100 \mathrm{~mA}$, 撮影時間 0.12 秒, 焦点・フィルム間距 離は $85 \mathrm{~cm}$ である。

\section{A. 研究刘象}

研究対象は前述した側斜位撮影と同じであり，成人男 子113名である.

\section{B. 研究方法}

前述した撮影法で得られた 113名の左右側顎関節 X 線 写真を次の項目について分析した。

\section{1. 下顎頭の形態分類}

下顎頭の形態を Yale ら (1966 ${ }^{5)}$ のX線解剖学的分 類に準して, convex, flat, round, angled, その他の 5 型㲹分類した。

2. 左右下買頭形態の対称性

前述した形態分類に基づき, 左右下顎頭の形態の比較 を行った。

3. 下顎頭頂部における concavity の出現頻度 正常下顎頭の上部関節表面には円滑な陷凹がしばしば
認められるが，てれは normal variation として認譏さ れている、そこで,この concavity の出現頻度を調べた。

4. 下顎頡骨皮質について

骨皮質の厚みおよび棈浩上の変化について調べた。す なわち, 内外側抢よび頂部の 3 部分に分けてその部位に おける骨皮質の厚みを調べた。

5. 下䫟頭骨髄腔の所見について 骨髄腔の㹡大の有無を調べた。

6. 下顎頭骨梁饥て

骨梁の排列, 走行の状態や情梁の密度について調べた。

7. 関節結簛骨皮質の状態

骨皮質の変化の有無の判定に関しては図11に示すよう に，全域にわたり明膫に認められるものを丁型，内側 $1 / 3$ の骨皮質が消失しているも0を II 型，中央 $1 / 3$ の骨皮質が 消失しているものを II 型，外側 $1 / 3$ の骨皮質が消失してい るものをIV型，関節結節全域にわたり骨皮質が消失して いるものをV型とした。

\section{8. 関節結節の形態分類}

图12に示すように関節結節が平坦なものをI型，不規

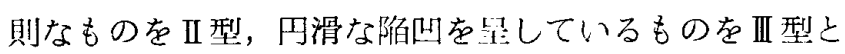
した.

9. 乳様突起，煩骨乫起および関節結節などによ る下顎頭への重なりの有無

乳様突起，煩骨突起，関節結節などが下顎頭任全く重 複しないものを I型, 下㖽頭の $1 / 3$ 亿重複するものを II

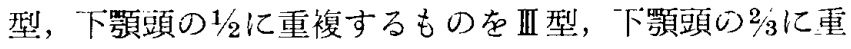

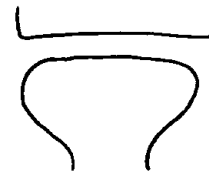

I 型

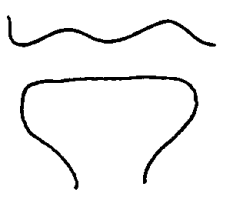

II 型

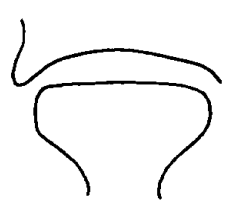

III 型
図12 模式的に示した関節結節の形態分類 （眼裔・下顎枝撮影法による） 


\begin{tabular}{c|c|c|c} 
表 1 & 再現性実 験 & \multicolumn{1}{c}{$\mathrm{mm}$} \\
\hline \hline 術者 $\mathrm{A}$ & $\overline{\mathrm{AB}}$ & $\overline{\mathrm{AC}}$ & $\overline{\mathrm{BC}}$ \\
\hline 1 & 28.82 & 56.48 & 34.75 \\
2 & 28.87 & 56.48 & 34.78 \\
3 & 28.63 & 56.32 & 34.85 \\
\hline Mean & 28.77 & 56.43 & 34.79 \\
\hline S. D. & 0.13 & 0.09 & 0.05 \\
\hline 術 者 B & $\overline{\mathrm{AB}}$ & $\overline{\mathrm{AC}}$ & $\overline{\mathrm{BC}}$ \\
\hline 1 & 29.38 & 56.53 & 34.50 \\
\hline 2 & 29.23 & 56.47 & 34.38 \\
\hline 3 & 29.57 & 56.80 & 34.45 \\
\hline Mean & 29.39 & 56.60 & 34.44 \\
\hline S. D. & 0.17 & 0.18 & 0.06 \\
\hline
\end{tabular}

複するものをIV 型, 下頢頭の全部に重複するものをV 型 とした.

\section{結 果}

I 、顎関節撮影におけるX線像の再現性について

表 1 は 3 枚のX線'写真の各計測值の平均值および熛準 偏差値である，術者 $\mathrm{A} の$ 場合, 再現性の最も悪いのは土 $0.13 \mathrm{~mm}$ であり,術者 $\mathrm{B}$ の場合は土0.18mmであった．い ずれの計測値および術者間の標準偏差值も $0.2 \mathrm{~mm}$ を越 えていないので撮影法の再現性は十分あると判断した.

II . 側斜位撮影

\section{A . 下顎頭の位置}

各群共に各撮影法における下顎頭の位置の分布に関し ては左右側間には有意差は噁められなかった（A群： $x^{2}{ }_{15^{\circ} / 0^{\circ}}=0, x^{2}{ }_{20} / 10^{\circ}=3.2, \mathrm{~B}$ 群: ${ }^{2} 20^{\circ} / 0^{\circ}=2.4$, $x^{2} 20^{\circ} / 10^{\circ}=0.4, \quad$ C 群: $x^{2} 25^{\circ} / 0^{\circ}=1.2, x^{2} 20^{\circ} / 10^{\circ}=$ 0.4 , D群: ${ }^{x^{2}} 30^{\circ} / 0^{\circ}=1.2, \quad x^{2} 20^{\circ} / 10^{\circ}=1.6, x^{2}$ (2,

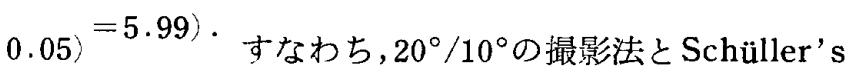

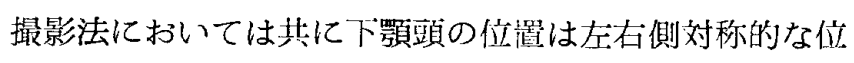
㯰にあることが判明した。

各群の両撮影法間における下顎頭の位置の分布につい ては，右側では有意差がみられなかった（A群: ${ }^{x^{2}} 15^{\circ}$ / $0^{\circ}-20^{\circ} / 10^{\circ}=3.6, \quad \mathrm{~B}$ 群 : ${ }^{x^{2}} 20^{\circ} / 0^{\circ}-20^{\circ} / 10^{\circ}=1.2$, C 群 : ${ }^{x^{2}} 25^{\circ} / 0^{\circ}-20^{\circ} / 10^{\circ}=0.4, \mathrm{D}$ 群: ${ }^{x^{2}} 30^{\circ} / 0^{\circ}-20^{\circ} /$

表 2 側斜位撮影における下顎頭骨皮質の状態

\begin{tabular}{|c|c|c|c|c|c|c|c|}
\hline $\begin{array}{l}\text { 群 } \\
\text { 別 }\end{array}$ & $\begin{array}{l}\text { 撮 } \\
\text { 影 } \\
\text { 法 }\end{array}$ & $\begin{array}{l}\text { 例 } \\
\text { 数 }\end{array}$ & $\begin{array}{c}\text { I } \\
\text { 型 }\end{array}$ & $\begin{array}{l}\text { II } \\
\text { 型 }\end{array}$ & $\begin{array}{l}\text { III } \\
\text { 型 }\end{array}$ & $\begin{array}{l}\text { IV } \\
\text { 型 }\end{array}$ & $\begin{array}{l}\mathrm{V} \\
\text { 型 }\end{array}$ \\
\hline \multirow{2}{*}{ A 群 } & & 100 & 95 & 0 & 2 & 2 & 1 \\
\hline & $15^{\circ} / 0^{\circ}$ & 100 & 91 & 0 & 3 & 3 & 3 \\
\hline \multicolumn{8}{|c|}{$\left(x^{2}=1.28\right)$} \\
\hline \multirow{2}{*}{ B 群 } & $20^{\circ} / 10^{\circ}$ & 100 & 95 & 1 & 4 & 0 & 0 \\
\hline & $20^{\circ} / 0^{\circ}$ & 100 & 91 & 0 & 6 & 1 & 2 \\
\hline \multicolumn{8}{|c|}{$\left(x^{2}=1.28\right)$} \\
\hline \multirow{2}{*}{ C 群 } & $20^{\circ} / 10^{\circ}$ & 100 & 93 & 2 & 4 & 1 & 0 \\
\hline & $25^{\circ} / 0^{\circ}$ & 100 & 90 & 0 & 8 & 2 & 0 \\
\hline \multicolumn{8}{|c|}{$\left(x^{2}=0.64\right)$} \\
\hline \multirow{2}{*}{ D 群 } & $20^{\circ} / 10^{\circ}$ & 100 & 95 & 0 & 3 & 0 & 2 \\
\hline & $30^{\circ} / 0^{\circ}$ & 100 & 96 & 0 & 2 & 0 & 2 \\
\hline
\end{tabular}

$\left.10^{\circ}=4.4, x_{(2,0.05)}^{2}=5.99\right)$. 左側では, B群の $20^{\circ} /$ $10^{\circ}$ において前方型と中央型を呈したのは，それぞれ3 例と 47 例であったが, $20^{\circ} / 10^{\circ}$ では前方型, 中央型, 後 方型が，それぞれ 5 例， 40 例， 5 例あり，両撮影法間に は有意差が認められた $\left(x^{2}=6.0>x^{2}(2,0.05)=5.99\right)$. $\mathrm{A}$ 群， C群， D群においては各撮影法間には有意差はみ られなかった（A群: ${ }^{x^{2}} 15^{\circ} / 0^{\circ}-20^{\circ} / 10^{\circ}=4.0, \mathrm{C}$ 群 : $x^{2} 25^{\circ} / 0^{\circ}-20^{\circ} / 10^{\circ}=1.6, \quad \mathrm{D}$ 群 : ${ }^{x^{2}} 30^{\circ} / 0^{\circ}-20^{\circ} / 10^{\circ}=$ $\left.4.8, x^{2}(2,0.05)=5.99\right)$. 方なおち, B 群の左側以外 は, 各群共に下顎頭の位置に関しては撮影法聞には差は ないことが判明した。

両撮影法共に下䫛頭が中央位に描出されたものは，A 群では75\%，B群では77\%，C群では 73\%，D群では $72 \%$ あった．各群において下顎頭の位置が一致したも のは，A群では $80 \% ， \mathrm{~B}$ 群では79\%，C群では $82 \% ， \mathrm{D}$ 群では $80 \%$ であった． $20^{\circ} / 10^{\circ}$ で得られた 400 側の下顎頭 の位犆については，中央位のものは 334 例 $(83.5 \%)$ と 最も多く，後方位のものは 45 例 $(11.3 \%)$, 前方位のも のは21例 $(5.3 \%)$ であった。

\section{B . 下頻頭哃皮質の状態}

下顎頭骨皮質の状態は表 2 に示すとおりである.各群 共にI型，すなわち，下顎頭骨皮質が明瞭に描出されて いる場合が多い，I型以外では, 他の型の出現頻度には 
表 3 例斜位撮影における下㖽窩骨皮質の状態

\begin{tabular}{|c|c|c|c|c|c|c|c|}
\hline $\begin{array}{l}\text { 群 } \\
\text { 別 }\end{array}$ & $\begin{array}{l}\text { 撮 } \\
\text { 影 } \\
\text { 法 }\end{array}$ & $\begin{array}{l}\text { 例 } \\
\text { 数 }\end{array}$ & $\begin{array}{c}I \\
\text { 型 }\end{array}$ & 型 & $\begin{array}{l}\text { III } \\
\text { 型 }\end{array}$ & $\begin{array}{l}\text { IV } \\
\text { 型 }\end{array}$ & 型 \\
\hline \multirow{2}{*}{ A } & $20^{\circ} / 10^{\circ}$ & 100 & 88 & 1 & 0 & 4 & 7 \\
\hline & $15^{\circ} / 0^{\circ}$ & 100 & 94 & 0 & 2 & 3 & 1 \\
\hline \multirow{3}{*}{ B 群 } & \multicolumn{7}{|c|}{$\left(x^{2}=2.2\right)$} \\
\hline & $20^{\circ} / 10^{\circ}$ & 100 & 82 & 1 & 4 & 7 & 6 \\
\hline & $20^{\circ} / 0^{\circ}$ & 100 & 93 & 1 & 0 & 4 & 2 \\
\hline \multicolumn{8}{|c|}{$\left(x^{2}=5.7\right)$} \\
\hline \multirow{2}{*}{ C 群 } & $20^{\circ} / 10^{\circ}$ & 100 & 71 & 5 & 7 & 13 & 4 \\
\hline & $25^{\circ} / 0^{\circ}$ & 100 & 69 & 2 & 5 & 19 & 5 \\
\hline \multicolumn{8}{|c|}{$\left(x^{2}=0.1\right)$} \\
\hline \multirow{2}{*}{ D 群 } & $20^{\circ} / 10^{\circ}$ & 100 & 87 & 0 & 4 & 5 & 4 \\
\hline & $30^{\circ} / 0^{\circ}$ & 100 & $59^{*}$ & 0 & 11 & 20 & 10 \\
\hline
\end{tabular}

有意差はなかった，各群共に両撮影法間における下顎頭 骨皮質の状態には有意差仗認められなかった $\left(x^{2}{ }^{2}=\right.$ $1.28, x^{2} \mathrm{~B}=1.28, x^{2} \mathrm{C}=0.64, x^{2} \mathrm{D}=0.13, x^{2}(2,0.05)$ $=5.99$. 以上の結策から, 撮影角度が変化しても下顩 頭骨皮質の現われ方には有意差はないということが判明 した。

\section{C．下顎窩肖皮質の状態}

下顎简骨皮質の状態は表 3 亿示すとおりである．各群 共にI型，すなわち，下顩窩骨皮質が明嘹に認められる 場合が多い，A群では，下蕷䆚常皮質の状態に関しては 再撮影法間には有意差はみられなかった $\quad x^{2}=2.2<x^{2}$ $(1,0.05)=3.84)$ が， B 群では，耐撮影法間汇有意差 がみられた $\left(x^{2}=5.7>x^{2}(1,0.05)=3.84\right)$. すなわち $20^{\circ} / 10^{\circ}$ より $20^{\circ} / 0^{\circ}$ の方が I型を示す率は高かった。 $\mathrm{C}$ 群では，两撮影法間には有意差はみられなかった $x^{2}$ $\left.=0.1<x^{2}(1,0.05)=3.84\right)$ が， D群では，両撮影法間 に有意差がみられた $\left(x^{2}=19.9>x^{2}\langle 1,0.05)=3.84\right)$. 寸なわち，30\% $10^{\circ}$ 上りも $20^{\circ} / 10^{\circ}$ の方が型を示す率が 滈かった，以上の結果から，下䫟窩骨皮質の検査法とし ては $20^{\circ} / 0^{\circ}$ がすぐれており, 次いで $15 \% 0^{\circ}, 25^{\circ} / 0^{\circ}$ の順 となる，少なくとも $30^{\circ} / 0^{\circ}$ は下䫇简常皮質の検査法には 適していない。

D．関節結節骨这質の状態

表 4 亿示すように，A群では，関節結節骨皮質の状態
表 4 側斜位撮影における関節結節骨皮質の状態

\begin{tabular}{|c|c|c|c|c|c|c|c|}
\hline $\begin{array}{l}\text { 群 } \\
\text { 別 }\end{array}$ & $\begin{array}{l}\text { 撮 } \\
\text { 法 }\end{array}$ & $\begin{array}{l}\text { 例 } \\
\text { 数 }\end{array}$ & $\begin{array}{c}I \\
\text { 型 }\end{array}$ & $\begin{array}{l}\text { II } \\
\text { 型 }\end{array}$ & $\begin{array}{l}\text { III } \\
\text { 型 }\end{array}$ & $\begin{array}{l}\text { IV } \\
\text { 型 }\end{array}$ & $\begin{array}{c}\mathrm{V} \\
\text { 型 }\end{array}$ \\
\hline \multirow{2}{*}{ A 群 } & $20^{\circ} / 10^{\circ}$ & 100 & $74 *$ & 9 & 1 & 0 & 16 \\
\hline & $15^{\circ} / 0^{\circ}$ & 100 & 91 & 2 & 1 & 0 & 6 \\
\hline \multicolumn{8}{|c|}{$\left(x^{2}=10.0\right)$} \\
\hline \multirow{2}{*}{ B 群 } & $20^{\circ} / 10^{\circ}$ & 100 & 78 & 6 & 0 & 1 & 14 \\
\hline & $20^{\circ} / 0^{\circ}$ & 100 & 82 & 5 & 0 & 0 & 13 \\
\hline \multicolumn{8}{|c|}{$\left\langle x^{2}=0.5\right\rangle$} \\
\hline \multirow{2}{*}{ C 群 } & $20^{\circ} / 10^{\circ}$ & 100 & 80 & 5 & 0 & 1 & 14 \\
\hline & $25^{\circ} / 0^{\circ}$ & 100 & 69 & 8 & 0 & 1 & 22 \\
\hline \multicolumn{8}{|c|}{$\left(x^{2}=3.2\right)$} \\
\hline \multirow{2}{*}{ D 群 } & $20^{\circ} / 10^{\circ}$ & 100 & 80 & 2 & 0 & 0 & 18 \\
\hline & $30^{\circ} / 0^{\circ}$ & 100 & 54 & 6 & 4 & 2 & 35 \\
\hline
\end{tabular}

に関しては両撮影法間に有意差がみられた $\left(x^{2} \mathrm{~A}=10.0\right.$ $\left.>x^{2}(1,0.05)=3.84\right)$.すなわち， I 型を示したものは $20^{\circ} / 10^{\circ}$ 上りも $15^{\circ} / 0^{\circ}$ の方が多かった。B群とC群では, 両撮影法開には有意差はみられな⿰力った $x^{2} \mathrm{~B}=0.5$, $x^{2} \mathrm{C}=3.2, x^{2}(1,0.05)=3.84$ ．D群では, 阔撮影法闘 亿有意差がみられた $\left(x^{2} \mathrm{D}=31.0>x^{2}\langle 1,0.05\rangle=3.84\right.$. すなわち，30\% $0^{\circ}$ よりも $20^{\circ} / 10^{\circ}$ の方が型を示したも のが多かった，以上の結果から，関節結節背皮質の検查 法としては， $15^{\circ} / 0^{\circ}$ が最もすぐれており，次いで $20^{\circ} \%$ $0^{\circ}, 25^{\circ} / 0^{\circ}$ の順となる. $30^{\circ} / 0^{\circ}$ は関節結節省皮質の検查 には適していない。

$\mathrm{E}$ 、錐体，鼓空部およびトルコ鞍の休状突起などに よる重なりの有無

表 5-1，5-2 亿示すように，錐体による重なりは

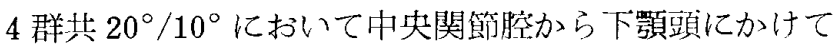
の重なりが多く，C群，D群では $25^{\circ} / 0^{\circ}$ と $30^{\circ} / 0^{\circ}$ におけ る重なりは少ない，鼓空部から後方関節腔にかけての重 なりに関しては，B群，C群においては $20^{\circ} / 0^{\circ}$ と $25^{\circ} / 0^{\circ}$ よりも $20^{\circ} / 10^{\circ}$ に扔ける重なりの方が多かった。休状突 起から前方関節腔にかけての重なりに関しては， B群， C 群に扔いては $20^{\circ} / 10^{\circ}$ よりも $20^{\circ} / 0^{\circ}$ と $25^{\circ} / 0^{\circ}$ における 重なりの方が多かった，以上の結果から，顎関節と他部 構造との重なりに関しては， $20^{\circ} / 10^{\circ}$ においては錐体や 鼓空部がそれぞれ中央関節腔と後方関節腔に重なりやす 
表 5-1 側斜位撮影における顎関節と錐体部との 重なり $(\mathrm{n}=30)$

\begin{tabular}{|c|c|c|c|c|c|}
\hline 群 & 別 & 撮影法 & $\begin{array}{l}\text { 中 央部 } \\
\text { 哭顎 窩 }\end{array}$ & $\begin{array}{l}\text { 中 央部 } \\
\text { 関節腔 }\end{array}$ & 下篔 頭 \\
\hline \multirow{2}{*}{ A } & \multirow{2}{*}{ 君 } & & $14(47 \%)$ & $25(83 \%)$ & $27(90 \%$ \\
\hline & & $15^{\circ} / 0^{\circ}$ & $4(13 \%)$ & $13(43 \%)$ & $29 \quad 97 \%$ \\
\hline \multirow{2}{*}{ B } & \multirow{2}{*}{ 群 } & $20^{\circ} / 10^{\circ}$ & $14(47 \%)$ & $25(83 \%)$ & $27(90 \%$ \\
\hline & & $20^{\circ} / 0^{\circ}$ & $5(17 \%)$ & $8(27 \%)$ & $30(100 \%$ \\
\hline \multirow{2}{*}{$\mathrm{C}$} & \multirow{2}{*}{ 群 } & & $7(23 \%)$ & $19(63 \%)$ & $30(100 \%$ \\
\hline & & $25^{\circ} / 0^{\circ}$ & $0(0 \%)$ & $1(3 \%)$ & $30(100 \%$ \\
\hline \multirow{2}{*}{$\mathrm{D}$} & \multirow{2}{*}{ 龵 } & $20^{\circ} / 10^{\circ}$ & $15(50 \%)$ & $27(90 \%)$ & $28(93 \%)$ \\
\hline & & $30^{\circ} / 0^{\circ}$ & $1(3 \%)$ & $6(20 \%)$ & $30(100 \%$ \\
\hline
\end{tabular}

い. A 群の $15 \% / 0^{\circ}$ においては，約 $40 \%$ 割合で前方関節 腔は床状乫起に, 中央関節腔は錐体に重なる，B群の $20^{\circ}$ $10^{\circ}$ では前方関節腔は床状突起に重なりやすい $(87 \%)$. C 群の $25^{\circ} / 0^{\circ}$ も同様江前方関節腔は床状突起に重なりや すい. $\mathrm{D}$ 群の $30^{\circ} / 0^{\circ}$ では他の解剖構造との重なりが最も 少ないようである。

F. 関節腔陌の明瞭度

表 6 亿示すように，後方関節腔の明暸度に関しては 4 群基 $20^{\circ} / 10^{\circ}$ との比較において有意差がみられた。挟， 前方関節腔の明瞭度に関しては, D群の中央関節腔を例 外とした場合，A，B，C群に扔いて中央, 前方，後方 関節腔つ明膫度には有意差はみられなかった。

$\mathrm{G}$. 下顎頭の形態分類

$20^{\circ} / 10^{\circ}$ で得られた 400 例下顝頭の形態において， 328
表 5-2 側斜位における顎関節と鼓公部および 朱状突起との重なり

$(\mathrm{n}=30)$

\begin{tabular}{|c|c|c|c|c|}
\hline 群 & 別 & 指 影 法 & $\begin{array}{c}\text { 後方部関節腔 } \\
\text { (鼓寉部) }\end{array}$ & $\begin{array}{c}\text { 前方部関節腔 } \\
\text { (休状突起) }\end{array}$ \\
\hline \multirow{2}{*}{ A } & \multirow{2}{*}{ 群 } & $20^{\circ} / 10^{\circ}$ & $19(63 \%)$ & $0(0 \%)$ \\
\hline & & $15^{\circ} / 0^{\circ}$ & $3(10 \%)$ & $11(37 \%)$ \\
\hline \multirow{2}{*}{ B } & \multirow{2}{*}{ 群 } & $20^{\circ} / 10^{\circ}$ & $22(73 \%)$ & $1(3 \%)$ \\
\hline & & $20^{\circ} / 0^{\circ}$ & $0(0 \%)$ & $26(87 \%)$ \\
\hline \multirow{2}{*}{$\mathrm{C}$} & \multirow{2}{*}{ 群 } & $20^{\circ} / 10^{\circ}$ & $21(70 \%)$ & $2(7 \%)$ \\
\hline & & $25^{\circ} / 0^{\circ}$ & $1(3 \%)$ & $20(67 \%)$ \\
\hline & \multirow{2}{*}{ 群 } & $20^{\circ} / 10^{\circ}$ & $22(73 \%)$ & $4(13 \%)$ \\
\hline & & $30^{\circ} / 0^{\circ}$ & $9(30 \%)$ & $3(10 \%)$ \\
\hline
\end{tabular}

例 $(82 \%)$ は人示指頭の形態を示し, 最も多かった. 次 いで尖鋭頭を示すもの57例 (14.2\%)，塊型，その他の 順となる. 左右側の対称性については, 左石対称的形態 を示したものは183例 $(91.5 \%)$ あった。

$\mathrm{H}$. 関節結節の形態分類

$20^{\circ} / 10^{\circ}$ で得られた新断に附えられる362例の関節結節 の中で，I型を示すものは 264 例 $(72.9 \%)$ あり最も多 い. 次いで II型が57例 $(15.8 \%) ， \mathbb{I I}$ 型が41例 $(11.3 \%)$ の順となる．関節結節の形態の左右差の有無に関して は，有意差はみられなかった $\left(x^{2}=5.6<x^{2}(2,0.05)=\right.$ 5.99)。すなわち，関節結節は左右対称的形態を呈して いるといえる。

I . 下顎窩の前後径および高さ

表 7-1に示すように有側下顎窩の前後径に関しては
表 6

\begin{tabular}{|c|c|c|c|c|c|c|c|c|c|c|c|c|c|}
\hline \multirow{2}{*}{ 群 } & \multirow{2}{*}{ 別 } & \multirow{2}{*}{ 撮影法 } & \multicolumn{4}{|c|}{ I 型 } & \multicolumn{3}{|c|}{ 型 } & \multicolumn{4}{|c|}{ IIII型 } \\
\hline & & & 前 方 & 中 央 & 後 & 方 & 前 方 & 中 央 & 後 方 & 前 7 & & 中 央 & 後 方 \\
\hline \multirow{2}{*}{$\mathrm{A}$} & \multirow{2}{*}{ 群 } & $20^{\circ} / 10^{\circ}$ & 16 & 19 & 7 & & 8 & 9 & 12 & 6 & & 2 & 11 \\
\hline & & $15^{\circ} / 0^{\circ}$ & 17 & 21 & 19 & & 11 & 6 & 6 & 2 & & 3 & 5 \\
\hline \multirow{2}{*}{ B } & \multirow{2}{*}{ 群 } & $20^{\circ} / 10^{\circ}$ & 19 & 23 & 12 & & 4 & 1 & 7 & 7 & & 6 & 11 \\
\hline & & $20^{\circ} / 0^{\circ}$ & 22 & 26 & 25 & & 4 & 2 & 4 & 4 & & 2 & 1 \\
\hline \multirow{2}{*}{$\mathrm{C}$} & \multirow{2}{*}{ 群 } & $20^{\circ} / 10^{\circ}$ & 15 & 18 & 12 & & 9 & 10 & 9 & 6 & & 2 & 9 \\
\hline & & $25^{\circ} / 0^{\circ}$ & 17 & 26 & 24 & & 5 & 6 & 3 & 8 & & 3 & 3 \\
\hline \multirow{2}{*}{ D } & \multirow{2}{*}{ 群 } & $20^{\circ} / 10^{\circ}$ & 14 & 12 & 11 & & 6 & 6 & 4 & 10 & & 12 & 15 \\
\hline & & $30^{\circ} / 0^{\circ}$ & 20 & 23 & 21 & & 5 & 2 & 1 & 5 & & 5 & 8 \\
\hline
\end{tabular}




\begin{tabular}{|c|c|c|c|c|c|c|c|c|c|}
\hline & & & & 平均值／標準偏差 & 例 & 平均值／標準偏差 & $\mathrm{t}$ & 一 検 定 & \\
\hline & & & 数 & 範 & 数 & 範 & $\begin{array}{l}20^{\circ} / 10^{\circ} \\
15^{\circ} / 0^{\circ}\end{array}$ & $\begin{array}{c}20^{\circ} / 10^{\circ} \\
\mathrm{R}-\mathrm{L}\end{array}$ & $\begin{array}{l}15^{\circ} / 0^{\circ} \\
\mathrm{R}-\mathrm{L}\end{array}$ \\
\hline \multirow{2}{*}{ A } & \multirow[b]{2}{*}{ 有 } & \multirow[b]{2}{*}{ 側 } & \multicolumn{2}{|r|}{$20^{\circ} / 10^{\circ}$} & \multicolumn{2}{|r|}{$15^{\circ} / 0^{\circ}$} & & & \\
\hline & & & 46 & $\frac{17.75 / 2.41}{13.7-22.4}$ & \multicolumn{2}{|r|}{$\frac{17.62 / 2.30}{12.7-22.9}$} & $\mathrm{~N} \cdot \mathrm{S}$. & \multirow{2}{*}{ N.S . } & \multirow{2}{*}{ N.S. } \\
\hline 群 & 左: & 側 & 45 & $\frac{17.27 / 2.41}{12.2-22.8}$ & 50 & $\frac{18.54 / 2.93}{12.4-26.3}$ & $\mathrm{~N} \cdot \mathrm{S}$. & & \\
\hline \multirow{2}{*}{ B } & \multirow[b]{2}{*}{ 右 } & \multirow[b]{2}{*}{ 側 } & \multicolumn{2}{|r|}{$20^{\circ} / 10^{\circ}$} & \multicolumn{2}{|r|}{$20^{\circ} / 0^{\circ}$} & & -- & \\
\hline & & & 45 & $\frac{18.58 / 2.15}{13.8-22.7}$ & 50 & $\frac{19.48 / 1.95}{14.8-23.3}$ & * & 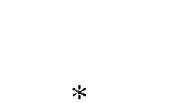 & \multirow{2}{*}{ N.S. } \\
\hline 群 & 左 & 側 & 44 & $\frac{18.03 / 2.43}{13.5-25.2}$ & 48 & $\frac{18.76 / 2.12}{14.1-24 \cdot 3}$ & $N \cdot S$. & & \\
\hline \multirow{2}{*}{$\mathrm{C}$} & \multirow[b]{2}{*}{ 有 } & \multirow[b]{2}{*}{ 側 } & \multicolumn{2}{|r|}{$20^{\circ} / 10^{\circ}$} & \multicolumn{2}{|r|}{$25^{\circ} / 0^{\circ}$} & & & \\
\hline & & & 48 & $\frac{19.42 / 2.67}{13.7-27.5}$ & 50 & $\frac{19.48 / 1.95}{14.8-23.3}$ & $*$ & \multirow{2}{*}{$*$} & \multirow{2}{*}{$*$} \\
\hline 群 & 左 & 側 & 45 & $\frac{18.01 / 2.25}{12.7-22.5}$ & 48 & $\frac{18.76 / 2.12}{14.1-24 \cdot 3}$ & $\ddot{*}$ & & \\
\hline \multirow{2}{*}{$\mathrm{D}$} & & & & $20^{\circ} / 10^{\circ}$ & & $30^{\circ} / 0^{\circ}$ & & & \\
\hline & 府 & 側 & 49 & $\frac{18.63 / 2.18}{14.3-24.3}$ & 46 & $\frac{20.06 / 2.78}{14.9-26.8}$ & $*$ & \multirow{2}{*}{$\mathrm{N} \cdot \mathrm{S}$. } & \multirow{2}{*}{ N.S } \\
\hline 群 & 左 & 側 & 46 & $\frac{18.17 / 2.72}{13.9-24.6}$ & 44 & $\frac{19.11 / 2.86}{14.3-28.0}$ & N.S. & & \\
\hline
\end{tabular}

B，C，D群共に $20^{\circ} / 10^{\circ}$ と比べた場合有意差がみられ た $(\mathrm{t}-$ test, $\mathrm{p}<0.05)$. 一方, 左側では， C群のみが $20^{\circ} / 10^{\circ}$ 之比べた場合有意差がみられた $(\mathrm{t}$ - test, $\mathrm{p}<$ 0.05). 各群の各種撮影法において左右側間に有意差が みられたのはB群，C群における $20^{\circ} / 10^{\circ}$ と群におけ る25\%/0であった（ $\mathrm{t}-$ test, $\mathrm{p}<0.05)$.

下顠窩の高さに関しては，各群共に各種撮影法間には 有意差はみられなかった $(\mathrm{t}$ - test, $\mathrm{p}<0.05)$. 各群の 各種撮影法において左右側閭に有意差がみられたのはA 群の $15^{\circ} / 0^{\circ}$ のみであった（t-test， $\mathrm{p}<0.05$ )

各群の $20^{\circ} / 10^{\circ}$ 亿おける右側 188 例の下顎窩の前後径は $18.6 \pm 2.34 \mathrm{~mm}$ であり, 左側 180 例の平均は $17.87 \pm$ $2.45 \mathrm{~mm}$ であった，下顎窩の前後径てついては左在側間 に有意差がみられた（ $\mathrm{t}$ - test， $\mathrm{p}<0.05)$ ，そこで，右側 下擷窩の前後径は左侧よりも大きいといえる．有側下顎 窩の高さは $7.28 \pm 1.46 \mathrm{~mm}$ であり，左側は $6.86 \pm 1.47$ $\mathrm{mm}$ であった，左在側の下顎窩の高さには有意差があり $(\mathrm{t}$ - test, $\mathrm{p}<0.05)$, 在側下頒窩の高さは左側よりも

\section{大きいといえる。}

下顎窩の前後径と高さとの相関は表 8 亿示すとおりで ある. B 群の $20^{\circ} / 10^{\circ}$ の右側以外は, 各群共に前後径と 高さとの間には正の相関関係がある $(\mathbf{p}<0.05)$.

\section{$\mathrm{J}$. 関節腔の幅径}

表 9-1〜9-4 は, 各群における各種撮影法の $20^{\circ} \%$ $10^{\circ}$ に対する各関節腔幅径の值である，前方および後方 部関節腔の幅径は各群共に菏撮影法間には有意差はみら れなかった（t-test， $\mathrm{p}<0.05)$. 不側の中央部関節腔 は， C 群とD群において $20^{\circ} / 10^{\circ}$ と $25^{\circ} / 0^{\circ}$ およ゙ $20^{\circ} / 10^{\circ}$ と $30^{\circ} / 0^{\circ}$ との間において有意差がみられた $\left({ }^{\mathrm{t}} \mathrm{R} 25^{\circ} / 0^{\circ}=\right.$ $\left.2.87,{ }_{\mathrm{R}}^{\mathrm{t}} 30^{\circ} / 0^{\circ}=3.74>\mathrm{t}=2.01, \mathrm{p}<0.05\right)$.

各群における $20^{\circ} / 10^{\circ}$ の左右側の関節腔幅径の值は, 前方部においては $6.0 \mathrm{~mm}$, 中央部では $3.6 \mathrm{~mm}$, 後方部 では3.5mmであった． $15^{\circ} / 0^{\circ}$ では，それぞれ $5.6 \mathrm{~mm}$ ， $3.5 \mathrm{~mm}, 3.7 \mathrm{~mm}$ であり, $20^{\circ} / 0^{\circ}$ では $5.6 \mathrm{~mm}, 3.3 \mathrm{~mm}$, $3.5 \mathrm{~mm}$ であり, $25^{\circ} / 0^{\circ}$ では $5.9 \mathrm{~mm}, 3.1 \mathrm{~mm}, 3.8 \mathrm{~mm}$ 
表 $7-2$

下 顎䈑 の 高さ

$\mathrm{mm}$

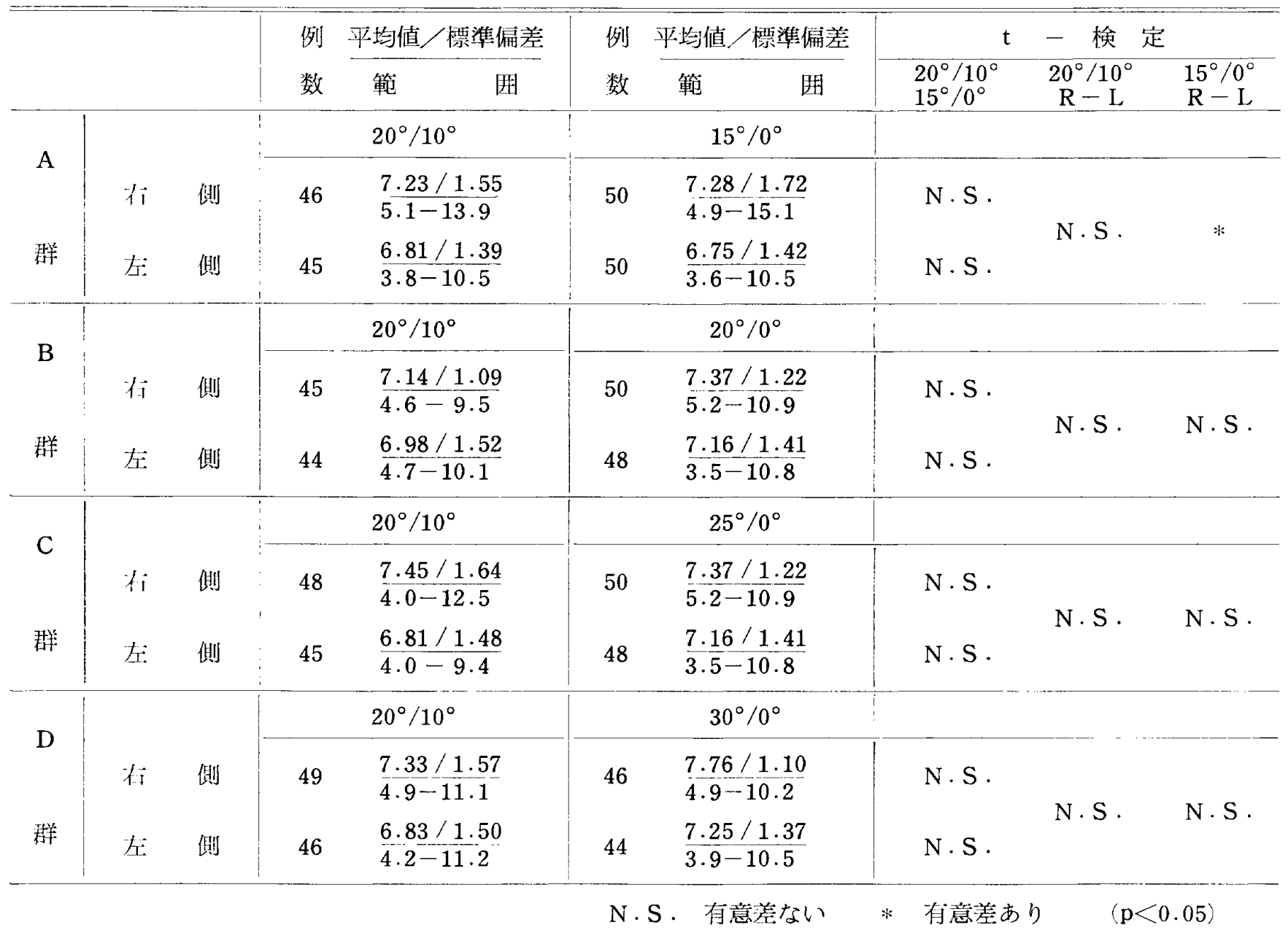

表 8

卜䫑简の前後径と高さとの相関

\begin{tabular}{|c|c|c|c|c|c|c|c|c|c|c|c|c|c|c|c|c|c|}
\hline \multirow{4}{*}{ A } & \multirow{4}{*}{ 群 } & \multicolumn{8}{|c|}{$20^{\circ} / 10^{\circ}$} & \multicolumn{8}{|c|}{$15^{\circ} / 0^{\circ}$} \\
\hline & & \multicolumn{2}{|r|}{ 在 } & \multicolumn{2}{|l|}{ 側 } & \multicolumn{2}{|r|}{ 左 } & \multicolumn{2}{|l|}{ 側 } & \multicolumn{2}{|r|}{ 右 } & \multicolumn{2}{|l|}{ 側 } & \multicolumn{2}{|r|}{ 庆: } & \multicolumn{2}{|l|}{ 側 } \\
\hline & & $\begin{array}{l}\text { 例 } \\
\text { 数 }\end{array}$ & $\begin{array}{l}\text { 相 } \\
\text { 閔 } \\
\text { 栠 } \\
\text { 数 }\end{array}$ & $\begin{array}{c}\mathrm{t} \\
\text { 值 }\end{array}$ & $\begin{array}{l}\text { 有 } \\
\text { 意 } \\
\text { 差 }\end{array}$ & $\begin{array}{l}\text { 例 } \\
\text { 数 }\end{array}$ & $\begin{array}{l}\text { 相 } \\
\text { 関 } \\
\text { 称 } \\
\text { 数 }\end{array}$ & $\begin{array}{c}\mathrm{t} \\
\text { 值 }\end{array}$ & $\begin{array}{l}\text { 有 } \\
\text { 意 } \\
\text { 差 }\end{array}$ & $\begin{array}{l}\text { 例 } \\
\text { 数 }\end{array}$ & $\begin{array}{l}\text { 相 } \\
\text { 関 } \\
\text { 絲 } \\
\text { 数 }\end{array}$ & $\begin{array}{c}\mathrm{t} \\
\text { 值 }\end{array}$ & $\begin{array}{l}\text { 有 } \\
\text { 荺 } \\
\text { 差 }\end{array}$ & $\begin{array}{l}\text { 例 } \\
\text { 数 }\end{array}$ & $\begin{array}{l}\text { 䅛 } \\
\text { 関 } \\
\text { 繁 }\end{array}$ & $\begin{array}{c}\mathrm{t} \\
\text { 值 }\end{array}$ & $\begin{array}{l}\text { 有 } \\
\text { 意 } \\
\text { 看 }\end{array}$ \\
\hline & & 46 & 0.30 & 2.08 & $*$ & 45 & 0.57 & 4.52 & $*$ & 50 & 0.50 & 3.96 & $*$ & 50 & 0.54 & 4.48 & $*$ \\
\hline \multirow{2}{*}{ B } & \multirow{2}{*}{ 群 } & \multicolumn{8}{|c|}{$20^{\circ} / 10^{\circ}$} & \multicolumn{8}{|c|}{$20^{\circ} / 0^{\circ}$} \\
\hline & & 45 & 0.27 & 1.85 & N.S. & 44 & 0.46 & 3.39 & $*$ & 50 & 0.45 & 3.50 & $*$ & 45 & 0.57 & 4.58 & $*$ \\
\hline \multirow{2}{*}{$\mathrm{C}$} & \multirow{2}{*}{ 群 } & \multicolumn{8}{|c|}{$20^{\circ} / 10^{\circ}$} & \multicolumn{8}{|c|}{$25^{\circ} / 0^{\circ}$} \\
\hline & & 48 & 0.37 & 2.73 & $*$ & 46 & 0.53 & 4.17 & $*$ & 48 & 0.52 & 4.11 & $*$ & 48 & 0.45 & 3.46 & $*$ \\
\hline \multirow{2}{*}{$\mathrm{D}$} & \multirow{2}{*}{ 群 } & \multicolumn{8}{|c|}{$20^{\circ} / 10^{\circ}$} & \multicolumn{8}{|c|}{$30^{\circ} / 0^{\circ}$} \\
\hline & & 50 & 0.47 & 3.74 & $*$ & 46 & 0.63 & 5.36 & $*$ & 46 & 0.44 & 3.28 & $*$ & 44 & 0.66 & 5.73 & $*$ \\
\hline
\end{tabular}

$\mathrm{N} . \mathrm{S}$. 有意差ない *有意差あり $(\mathrm{p}<0.05)$ 


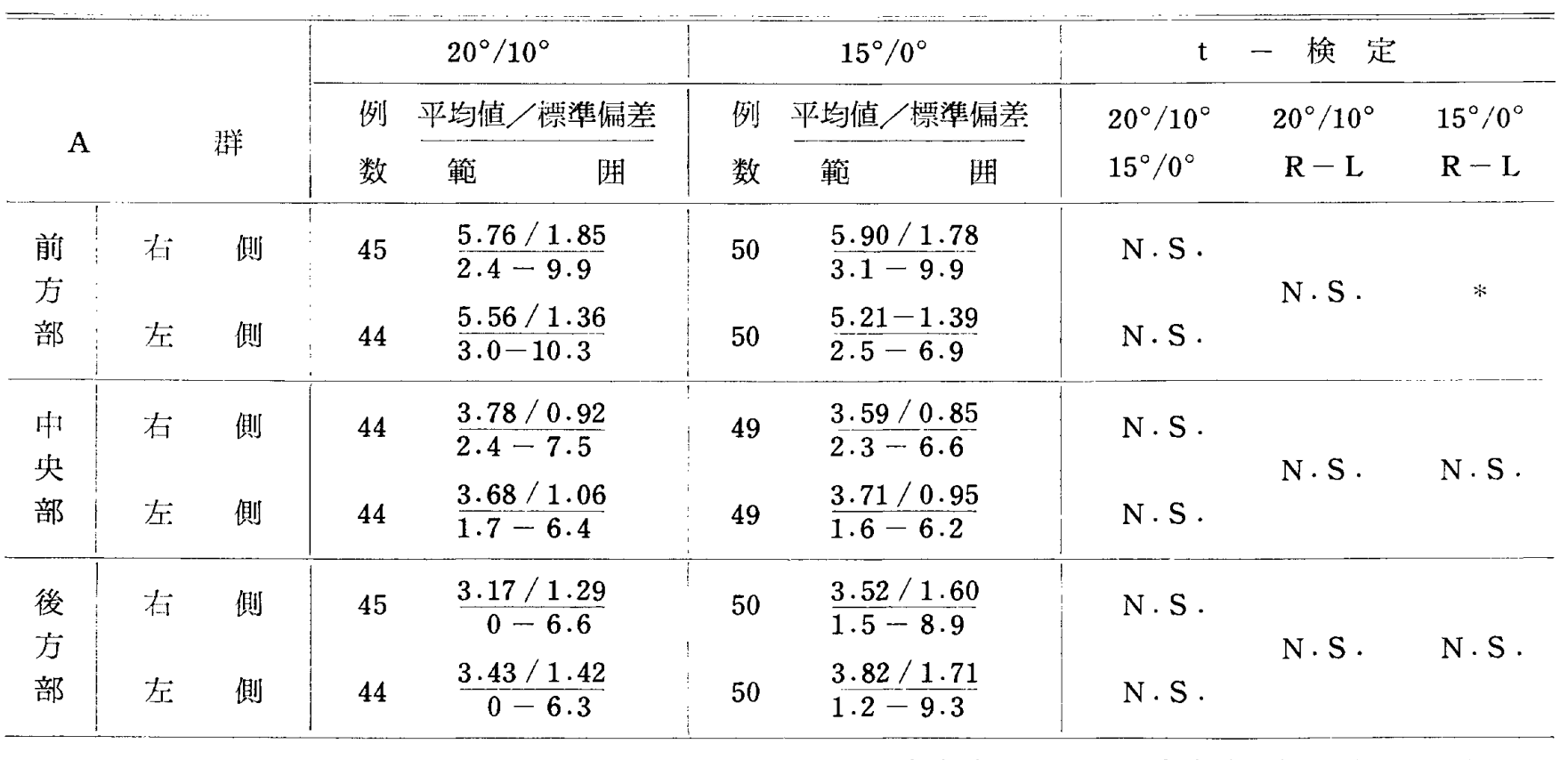

$\mathrm{N} \cdot \mathrm{S}$. 有意差ない * 有意差あり $\quad(\mathrm{p}<0.05\rangle$

表 $9-2$

各部位における関節腔の幅径

$\mathrm{mm}$

\begin{tabular}{|c|c|c|c|c|c|c|c|c|c|}
\hline & & & & $20^{\circ} / 10^{\circ}$ & & $20^{\circ} / 0^{\circ}$ & $\mathrm{t}$ & 一検 定 & \\
\hline $\mathrm{B}$ & & 样 & 例 & 岖均値／標準偏差 & 例 & 平均值／標淮偏差 & $20^{\circ} / 10^{\circ}$ & $20^{\circ} / 10^{\circ}$ & $20^{\circ} / 0^{\circ}$ \\
\hline $\mathbf{L}$ & & 䂥 & 数 & 囲 & 数 & 囲 & $20^{\circ} / 0^{\circ}$ & $\mathrm{R}-\mathrm{L}$ & $\mathrm{R}-\mathrm{L}$ \\
\hline 前j & 仿 & 側 & 45 & $\frac{5.99 / 1.50}{3.2-8.9}$ & 49 & $\frac{5.61 / 1.44}{2.9-10.1}$ & $N \cdot S$. & & \\
\hline 部 & 左 & 側 & 43 & $\frac{5.61 / 1.49}{2.7-9.0}$ & 49 & $\frac{5.57 / 1.49}{2.0-9.0}$ & N.S. & N.S. & $\mathrm{N} \cdot \mathrm{S}$. \\
\hline 计 & 有 & 側 & 44 & $\frac{3.42 / 0.91}{1.5-5.1}$ & 49 & $\frac{3.09 / 0.88}{1.1-5.1}$ & N.S . & & \\
\hline 部 & 左 & 側 & 43 & $\frac{3.65 / 1.02}{1.7-5.8}$ & 49 & $\frac{3.55 / 0.82}{1.7--5.4}$ & N.S & N.S. & * \\
\hline 後 & 右 & 側 & 43 & $\frac{3.25 / 1.03}{1.6-6.2}$ & 48 & $\frac{3.34 / 1.13}{1.8-7.3}$ & N.S . & & \\
\hline $\begin{array}{l}\text { 万 } \\
\text { 部 }\end{array}$ & 左 & 側 & 42 & $\frac{3.58 / 1.36}{1.6-7.3}$ & 48 & $\frac{3.62 / 1.01}{1.9-5.9}$ & $N \cdot S$. & $\mathrm{N} \cdot \mathrm{S}$ & $N \cdot S \cdot$ \\
\hline
\end{tabular}

であり, $30^{\circ} / 0^{\circ}$ では $6.1 \mathrm{~mm}, 3.0 \mathrm{~mm}, 3.5 \mathrm{~mm}$ であっ た.以上の結果から関節腔幅径は前方部が最も広く，中 央部と後方部の幅はほぼ等しいといえる，各部位の関節 腔幅径の比を求めると， $30^{\circ} / 0^{\circ}$ では前方：中央：後方 $=$ $1.7: 0.9: 1.0$ 上なり, $25^{\circ} / 0^{\circ}$ では $1.6: 0.8: 1.0,20^{\circ} \%$ 0 では $1.6: 1.0: 1.0,15^{\circ} / 0^{\circ}$ では $1.5: 1.0: 1.0,20^{\circ} \%$ $10 \circ$ では $1.7: 1.0: 1.0$ となる。
$\mathrm{K}$ ．その他

osteophyte は 400例中 6 例認められた．図13はその 1 例であり，下顎頭の前上方部に osteophyte がみられ る.

乳様突起が異常に発達した場合, 乳乫蜂巣 (紐胞) が 関節結節にまでおよぶことがある。このような症例が 400例中15例あった。図14はその1例である。 


\begin{tabular}{|c|c|c|c|c|c|c|c|c|c|}
\hline \multirow{3}{*}{ C } & \multirow{3}{*}{\multicolumn{2}{|c|}{ 群 }} & \multicolumn{2}{|r|}{$20^{\circ} / 10^{\circ}$} & \multicolumn{2}{|r|}{$25^{\circ} / 0^{\circ}$} & \multicolumn{3}{|c|}{ t 一 検 定 } \\
\hline & & & \multirow{2}{*}{$\begin{array}{l}\text { 例 } \\
\text { 数 }\end{array}$} & 平均值／標準偏差 & \multirow{2}{*}{$\begin{array}{l}\text { 例 } \\
\text { 数 }\end{array}$} & 平均值／氉準偏差 & \multirow{2}{*}{$\begin{array}{l}20^{\circ} / 10^{\circ} \\
25^{\circ} / 0^{\circ}\end{array}$} & \multirow{2}{*}{$\begin{array}{c}20^{\circ} / 10^{\circ} \\
\mathrm{R}-\mathrm{L}\end{array}$} & \multirow{2}{*}{$\begin{array}{l}25^{\circ} / 0^{\circ} \\
R-L\end{array}$} \\
\hline & & & & 範＜wide>囲 & & 範 囲 & & & \\
\hline $\begin{array}{l}\text { 前 } \\
\text { 方 }\end{array}$ & 右 & 側 & 48 & $\frac{5.84 / 1.36}{3.0-9.0}$ & 48 & $\frac{6.01 / 1.52}{3.3-9.4}$ & $\mathrm{~N} \cdot \mathrm{S}$. & \multirow{2}{*}{$N \cdot S$. } & \multirow{2}{*}{ N.S. } \\
\hline 部 & 左 & 側 & 45 & $\frac{5.87 / 1.34}{3.7-8.9}$ & 48 & $\frac{5.87 / 1.52}{3.2-8.7}$ & $\mathrm{~N} \cdot \mathrm{S}$. & & \\
\hline \multirow{2}{*}{$\begin{array}{l}\text { 中 } \\
\text { 央 } \\
\text { 部 }\end{array}$} & 右 & 側 & 47 & $\frac{3.43 / 0.99}{1.6-6.5}$ & 47 & $\frac{2.88 / 0.84}{1.7-5.7}$ & $*$ & \multirow{2}{*}{$\mathrm{N} \cdot \mathrm{S}$. } & \multirow{2}{*}{ N.S. } \\
\hline & 左: & 側 & 43 & $\frac{3.28 / 1.19}{0.65-6.1}$ & 47 & $\frac{3.22 / 0.94}{1.4-5.7}$ & $\mathrm{~N} \cdot \mathrm{S}$ & & \\
\hline \multirow{2}{*}{$\begin{array}{l}\text { 後 } \\
\text { 方 } \\
\text { 部 }\end{array}$} & 在 & 側 & 48 & $\frac{3.70 / 1.69}{0.7-10.0}$ & 48 & $\frac{3.86 / 1.52}{1.7-10.0}$ & N.S. & \multirow{2}{*}{$\mathrm{N} \cdot \mathrm{S} \cdot$} & \multirow{2}{*}{ N.S. } \\
\hline & 左 & 側 & 45 & $\frac{3.59 / 0.97}{1.4-5.6}$ & 48 & $\frac{3.67 / 0.96}{1.5-5.6}$ & $\mathrm{~N} \cdot \mathrm{S}$ & & \\
\hline
\end{tabular}

$\mathrm{N} \cdot \mathrm{S}$. 有意差ない * 有意差あり $(\mathrm{p}<0.05)$

表 $9-4$ 各部位における関節腔の幅径

$\mathrm{mm}$

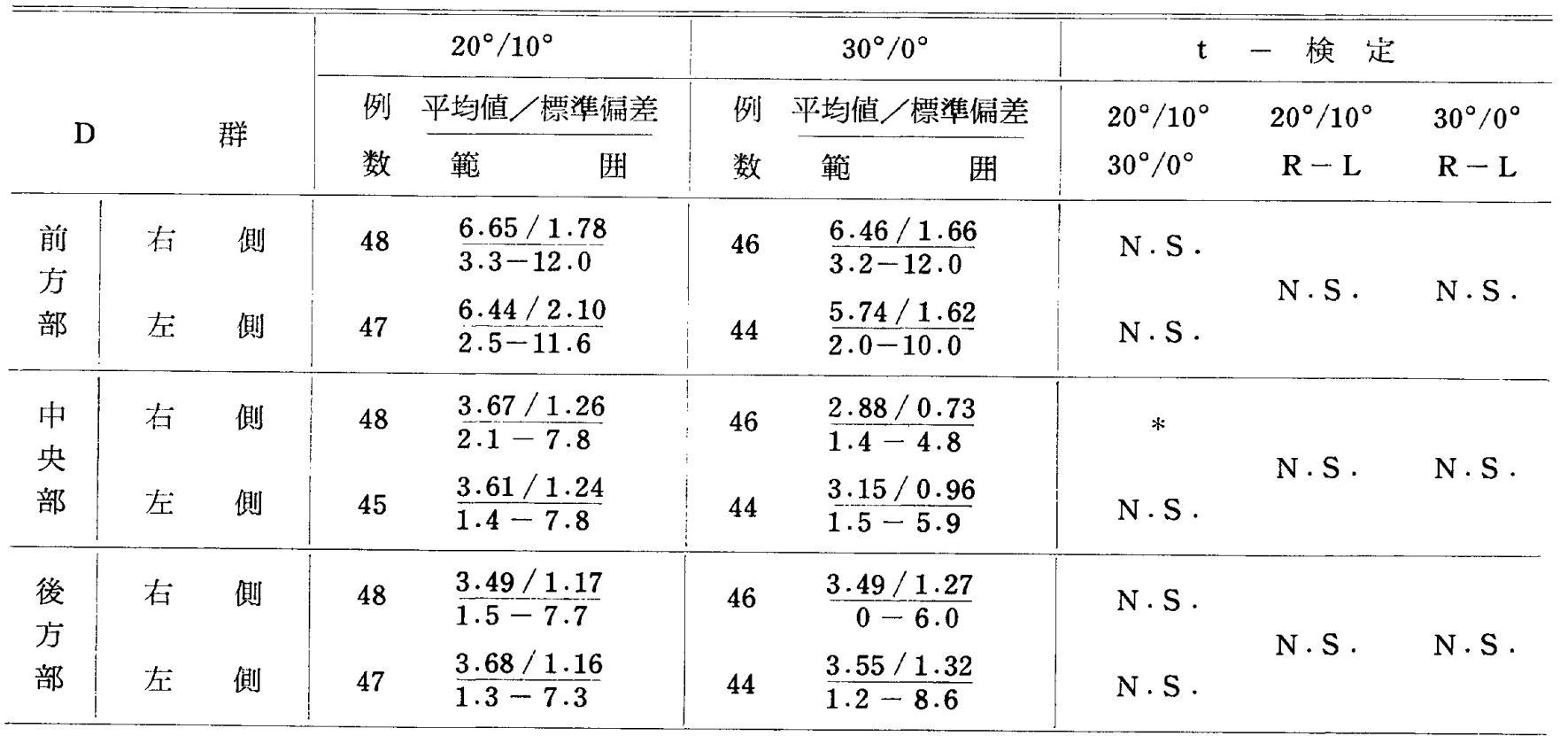

N.S. 有意差ない *有意差あり $\quad(\mathrm{p}<0.05)$

\section{III . 眼窝撮影}

\section{A. 下顎頭の形態分類}

表10に示すように， convex が最も多くみられ全体の $61.5 \%$ を占めている. 次いで round $(19.9 \%)$, flat $(13.2 \%)$ ，その他 $(3.6 \%)$, angled $(1.8 \%)$ の順となる。

B . 左右下顎頭形態の対称性

左有下顎頭の対称性は強く，中でも cnovex を示すも
のは63例 $(55.8 \%)$ あったが，それらは左右対称性を示 した．各種形態の下澦頭においても，左右下䫛頭の形態 においては有意差はみられなかった $\left(x^{2}=1.6<x^{2}(4\right.$ ， $0.05 ＝ 9.49 ＼mathrm{~ . ~ す な わ ち ， 下 䝷 頭 の 形 態 は 左 右 対 称 性 を ~}$ 示すものが多いといえる。

C 、下靧頭頂部における concavity の出現頻度 concavity 夻認めたものは 226 例中 14 例 (6.2\%) あ 


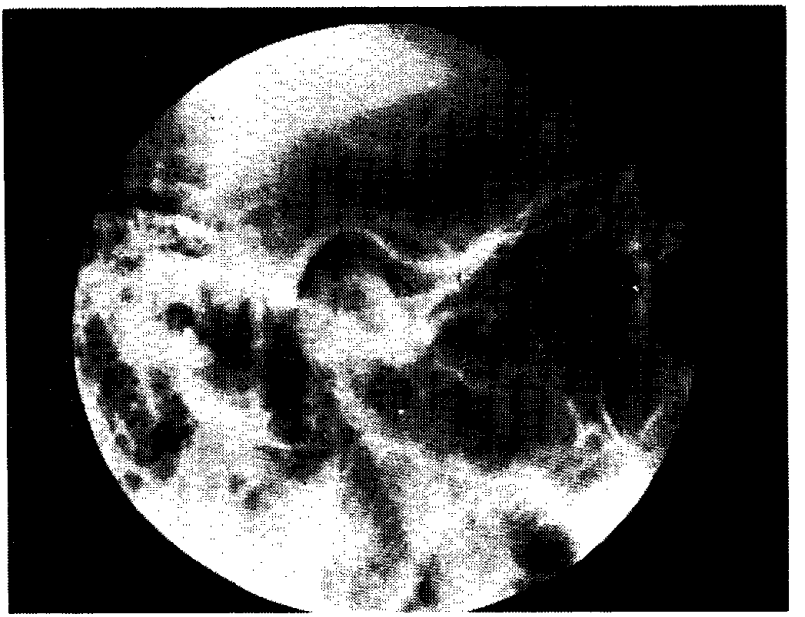

図13 下顎頭の前上部にosteophyteがみられる(印印)

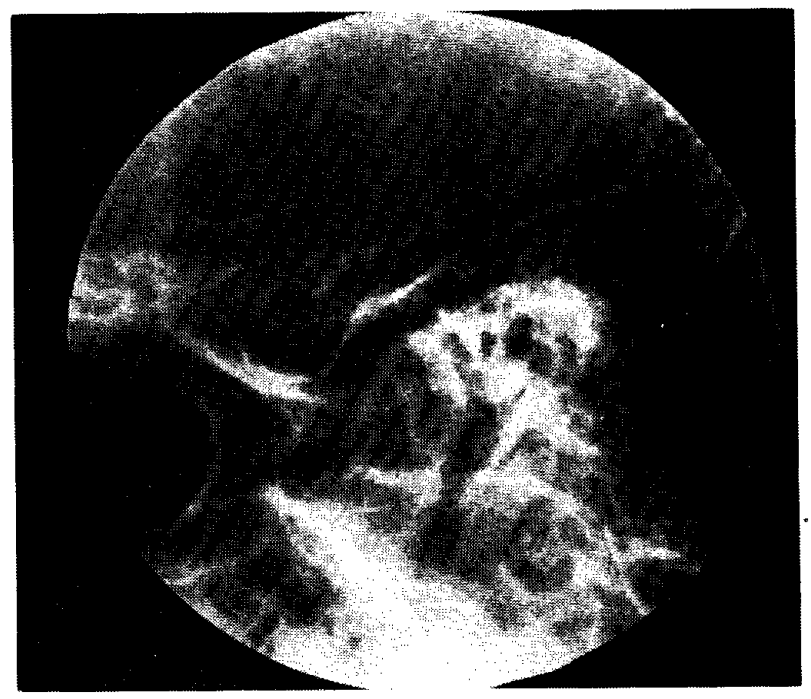

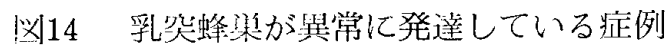

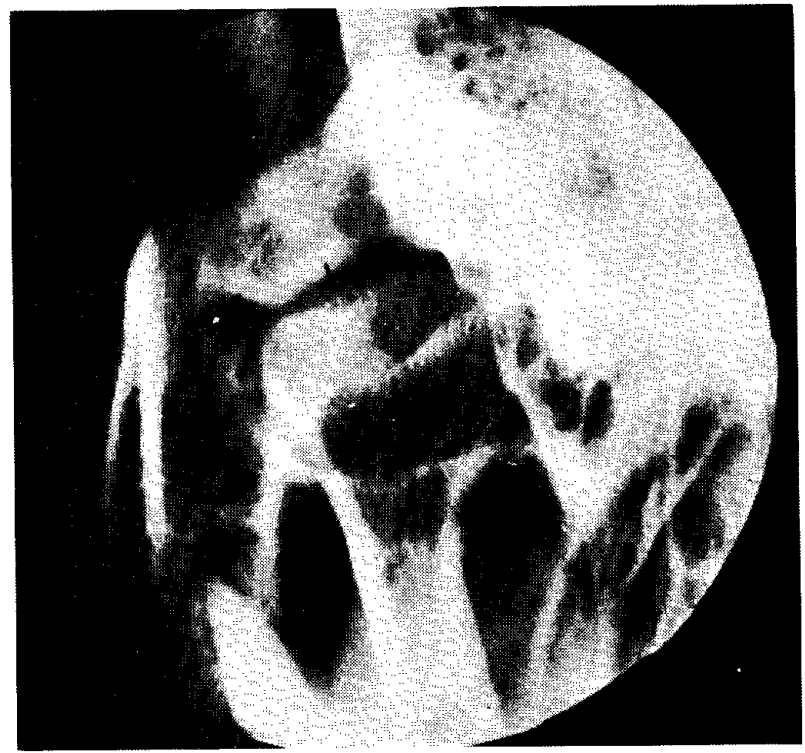

図15下顎頭頂部に concavity 認める症例（大印）

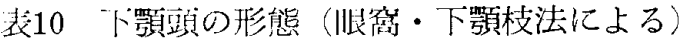

$\mathrm{n}=226$

\begin{tabular}{c|c|c|c|cc|cc}
\hline \hline & & & & & & & \\
\hline
\end{tabular}

り, 部位別では右側の外側部に 1 例, 中央部に 5 例, 左 側の外側に 1 例，中央部に 7 例あった. concavity は应

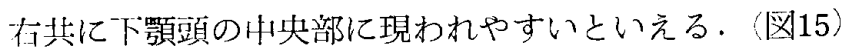

D. 下顎顕骨支質について

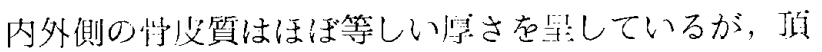
部の肢皮質は内外側に比べいぶん溥い，中には頂部に は情没質を倠認することができない場合もある。

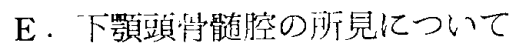

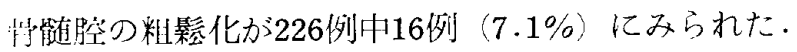
粗鬆化の!現には龙存はなかったが存在部位について は左不期に中央と外側に多くみられた。《図16〉

F . 下顎頭尚梁について

一般江崶梁は整然と排列しており，その排列状態は関 節面に対して西淔に起行している。図17に亦した例は代 表的な䇰梁の 1 例である。

\section{G. 関節結節訬皮質の状態}

226例中181例は診断に耐え得る関節結節のX線听胃を 1!したものであり，その中の177例 $(97.8 \%$ ）は明膫な

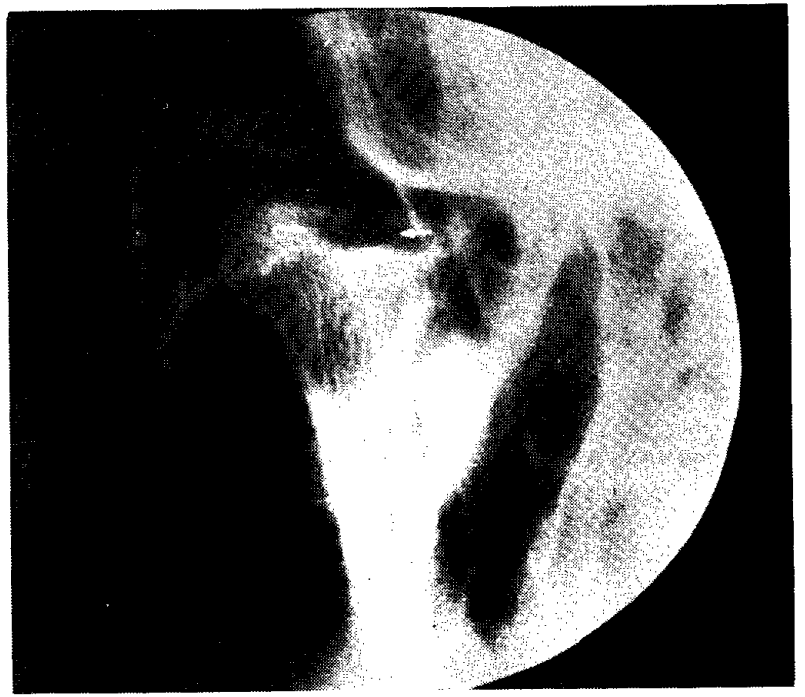

図16 下顎頭の霄髄腔に粗䉘化がみられる症例( 矢印) 
表11 関節結節の形惎（眼窩・下顎枝法による）

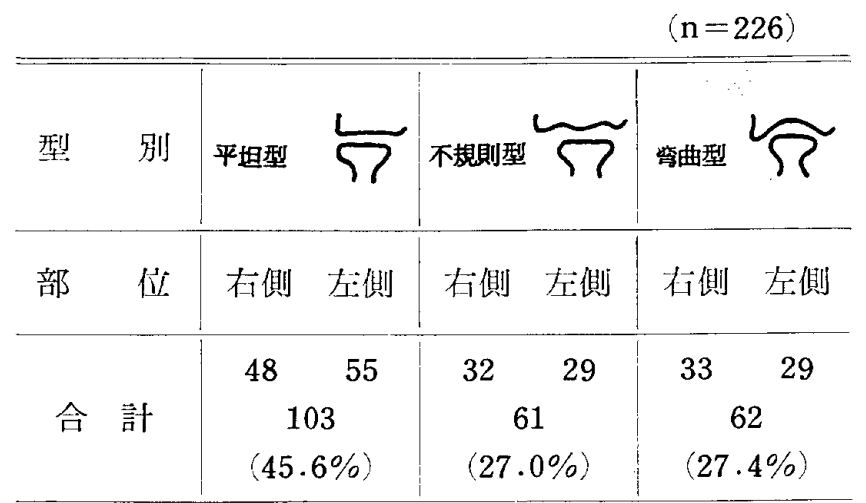

骨皮質を呈した。いわゆる工型を示したものが最も多か った。 II 型〜 V 型は右側にそれぞれ1例ずつみられた。

H . 関節結節の形態分類

表11に示すように平坦型の占める制合が最も多く $(45.6 \%)$, 次いで彎曲型と不規則型の順となる。各型 は左右側に扔い，ほぼ同し頻度で出現している。

I . 乳様突起，煩骨突起および関節結節などによる 下顎頭との重なりの有無

表12-1 は乳様突起による重なりの状態を示したもの で，I型および型を示すものは全体の84.9\%を方めて いる. 表12-2 は煩骨突起による重なりの状態を示した

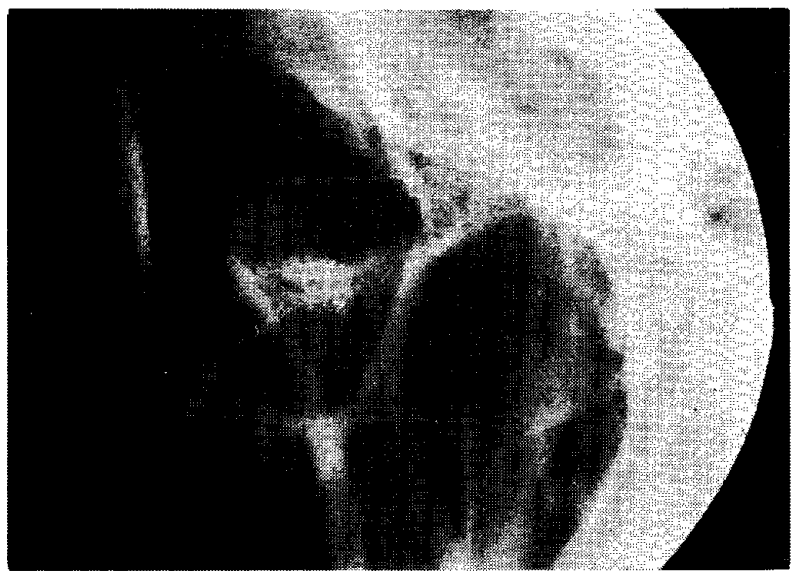

网17舆型的な下顎頭骨梁を呈する症例

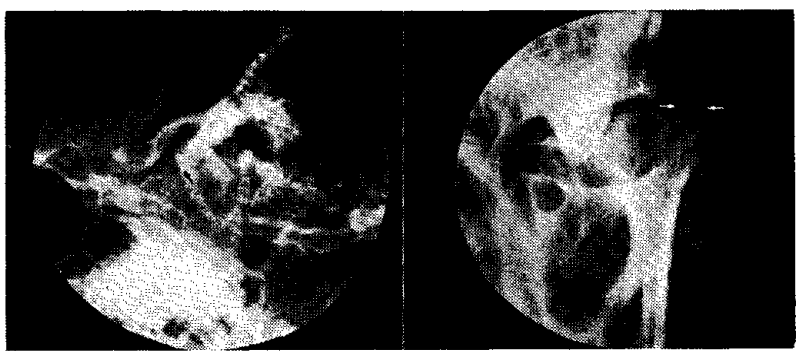

図18 osteophyte が側斜位と眼窩法共に抢いてみ られる症例（矢印）
もので，I型およびI型を示すものが全体の $99.1 \%$ 白 めている，表12-3 は関節結節と下頢頭との重なりを示 したもので，I型および而型が全体の 96\%をらうめてい

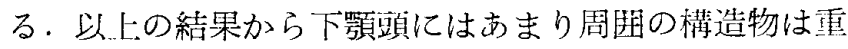
複しないといえる。

\section{J . その他}

osteophyte を思わせるX線不透過像を呈したものが 226 例中 6 例あった。図18にその 1 例を示す。

$$
\text { 考察 }
$$

顎関節のX楾検查法として古くから数多くの方法が利 用されている、顎関節は解乵学的に複雑な構造を呈して いるため，X線検查や誌影にはかなりの困難が生じる. そこで, 顎関節の撮影においては多方向からの観祭が望 ましい，しかし，現実問題として，X線検査をむやみに 増やすととは患者の被晎量を増加する結果となり，臨床 上大きな問題となる。そのような理由から，顎関節X線 検查法の選択や読影は重要な事項となる。

表12-1 下顎頭と乳様突起との重なり

$$
\text { (眼窩・下顎枝法による) } \quad(n=226)
$$

\begin{tabular}{|c|c|c|c|c|c|}
\hline 重複程度 & I 型 & II 型 & III & IV 型 & $\mathrm{V}$ \\
\hline 部 位 & R $\quad \mathrm{L}$ & $\mathrm{L}$ & $\mathrm{R}$ & $\mathrm{R}$ & $\mathrm{R}$ \\
\hline \multirow{3}{*}{ 合 涻十 } & $45 \quad 19$ & $\begin{array}{ll}57 & 71\end{array}$ & 8 & 2 & 1 \\
\hline & \multirow{2}{*}{$\begin{array}{c}64 \\
28.3 \%\end{array}$} & 128 & 28 & 5 & 1 \\
\hline & & $56.6 \%$ & $12.4 \%$ & $2.2 \%$ & $0.5 \%$ \\
\hline
\end{tabular}

表12-2 下顎頭と煩骨哭起との重なり

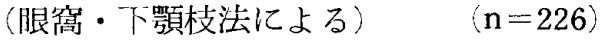

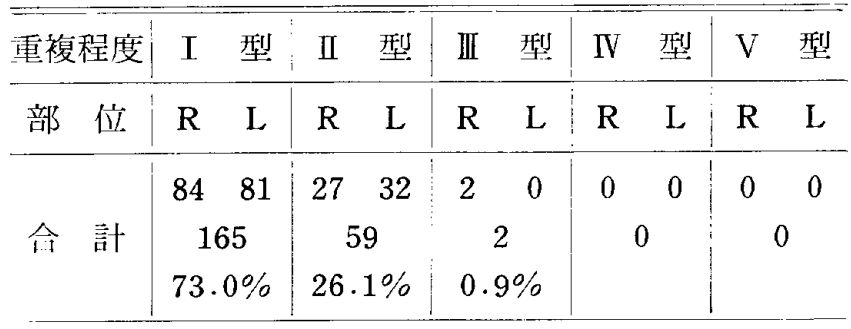

表12-3 下顎頭と関節結節との重なり (眼简・不顎枝法による)

$$
(\mathrm{n}=226)
$$

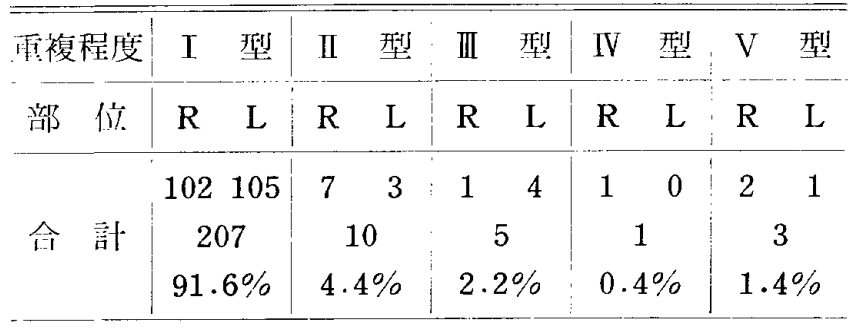


X線検査法の選択に関しては, Petersson弓 (1975) ${ }^{62}$ は顎関節の transcranial projection, transmaxillary projectionの 2 方法を用いて，下顎頭のerosion, flattening, osteophyte, sclerosis, subchondral pseudocyst, concavity, calcification などの有無について診 断能を比較している. 彼らの結論は再者を併用すること により,より多くの病変を検出できるとしている。 Hansson ら (1978) ${ }^{7}$ はさらに transpharyngeal, transmaxillary, oblique lateral transcranial projection の 3 方法で87名の䝷関節異常者についてX線彰 断能の比較検討を行い次心よう結果を得ている.

1. Transcranial projection の検出能は他の撮影法 に比べ最も良く，大部分の病変が検出できる．他の 2 方 法を併用することによりX線診断能はさらに向上する。

2. Transpharyngeal projection は下頭窩や関節結 節の病変の検出には適していない。

3. Transcranial projection では下顎頭の osteophyte が最も多く検出され，次いで sclerosis と flattening が検出された。 Transmaxillary projection では erosion は transcranial projection の 2 倍多く 検出された。

4. 顎関節のX線検査法として 1 種類を利用する 場合には transcranial projection が良い。次いで transmaxillary projection, transpharyngeal projection の順となる。

ところで 側斜位撮影は顎関節の側方像の描出は可能 であるが正面像は得られないという点がある8 .そこ で，顎関節の正面像を得る撮影法として，眼窩撮影が必 要となる．顎関節のX線所見と剖検所見との対比の研究 において，側斜位撮影は多くの病変を茪落したという報 告があり，見落された病変は関節結節におけるものが特 に多(19,10). Moffett (1974)11)は退行性額関節炎の初 期骨変化は関節結節に多くみられたと報告している。ま た，下顎頭や関節絬節の形態や大きさの把握にも眼窩撮 影は役立っている6，12)。

以上の理由から本研究では側斜位撮影および眼裔撮影 の両撮影法を評価する目的で，両撮影法により得られた 正常顎関節 X 線像の分析を行った。

I . 側斜位撮影について

側斜位撮影は X線の入射点および入射角度の違いによ り，種々な撮影法に分類できる13)。その中で臨休的に多 く利用されているのは Schüller's法である. Schüller's 法に拉いても X線の入射角度は一定ではなく，垂直方向 の角度は $15^{\circ}$ から $30^{\circ}$ まで種々ある. $15^{\circ}$ から $30^{\circ}$ までの中
でも，どの角度が臨床に適しているかということに関し てはいまだ定説はない14，その理由の一つとして，下 顎頭忧解剖学的に水平および垂直方向の角度において個 体差が大きいからである5゙，また，顎関節の形隼および 大きさにおいても個体差が強いことが挙げられる．側斜 位撮影における垂直方向のX線の入射角度は, 蝶形骨や 側頭骨の錐体部との重なりを避けるため $15^{\circ}$ 以下にしな い方が良いと Craddock（1953）15'は述べている。X線 入射角度の変化倸よるX線像の変化関する基礎実験と して, Egli (1969) 16), Tveito (1974) 17), 金箖 (1981) 14) などの研究がある。いずれの研究も対象とした頭䕊の例 数が少ないため，形態の個体差もあることなどから顎関 節撮影の絶対的な研究とはいいがたい。

一方, Schüller's法の撮影角度に関する研究は比較的 に少ない．Kundert $(1976)^{18)}$ は顎関留疾患77症例 (150 側〉を対象にして, Frankfort 水平面に対し $30^{\circ}$ 傾斜し た撮影法の描出率は $82 \%$ であったとしている，Geering $(1975)^{191}$ は 72名の 顎関節疾患の患者を 対象にして，

Richard 氏法（水平面に対して上方 $25^{\circ}$ 傾けて，さらに 证中矢状面に対し前方入 $12^{\circ}$ 傾斜する) と Lindblom 氏 法（C字型の頭部固定装置を用い，上方へ $15^{\circ}$ 傾斜さ せ, 前方へ $15^{\circ}$ 傾斜させる) を比較しているが，前者の方 が後者よりもすぐれるという結果を出している．Palla
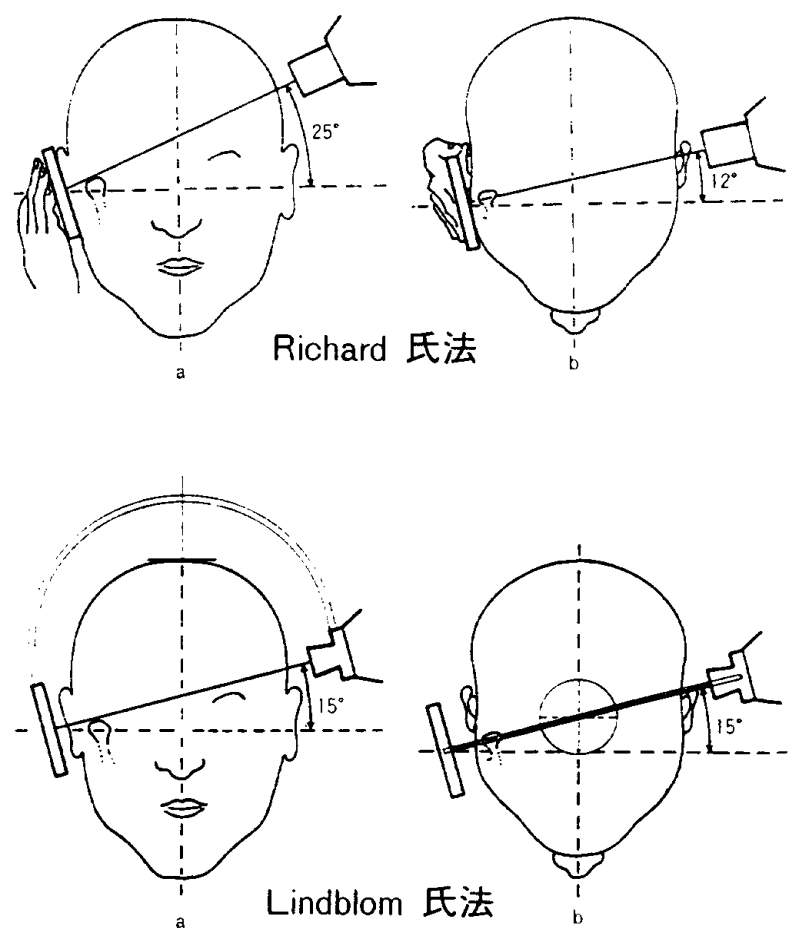

図19 模式的に示した Richard 氏法と Lindblom 氏 法 (Geering (1975) ${ }^{19}$ 加引引用) 
$(1976)^{20}$ は平均角度 (上方へ $22^{\circ}$ 傾斜させ, 前方へ $10^{\circ}$ 傾斜させる）による方法と個別に求めた角度に上る方法 との比較を行っているが，両者共に描出率は約 $80 \%$ であ ったと述べている．以上のように固定角度（X線入射角 度は上方へ $15^{\circ} \sim 30^{\circ}$ 傾斜させ, 前方へ $0^{\circ} \sim 15^{\circ}$ 傾斜させ る）では 70〜80\% の描出率が得られるようである ${ }^{18)}$. 著者の研究においてもほぼ同椂の描出率を得た．すなわ ち, $\mathrm{A}$ 群, $\mathrm{B}$ 群, $\mathrm{D}$ 群における本学の撮影〈眼耳平面に 対し，上方へ $20^{\circ}$ 傾斜させ，正中矢状面に対し，前方へ $10^{\circ}$ 傾斜させる，以下 $20^{\circ} / 10^{\circ}$ と略す) の描出率は約 $70 \%$ であった、A群とB群における本学撮影と対比した $15 \%$ $0^{\circ}$ (眼耳平面に対し, 上方へ $15^{\circ}$ 傾斜させる) と $20^{\circ} / 0^{\circ}$ (眼耳平面に対し，上方へ $20^{\circ}$ 傾斜させる) とは僅かに $4 \%$ 高い描出率を占めている。D群における $30^{\circ} / 0^{\circ}$ （眼 耳平面に対し，上方一 $30^{\circ}$ 傾斜させる）による方法は最 も描出率が悪く40\%であった。これは Kundert（1976） 18) の $30^{\circ} / 0^{\circ}$ による描出率 $82 \%$ と比べた場合大差があ る.本研究と他の研究における結果の間に差が生じたの は，X線像の判定基準に差があるからだと考える、すな わち，著者は下顎頭，下靧窩，関節結節共にすべて骨皮 質が明瞭に描出されたものを明瞭なXX線像とみなした。 表14に示すように各項目別に各群の描出率をみると，下゙ 顎頭の描出に関しては各群共に $20^{\circ} / 10^{\circ}$ とは大差はなく, 高い描出乘を示している．下顎窩骨皮質の描出には $15 \%$ $0^{\circ}$ と $20^{\circ} / 0^{\circ}$ が適していると考える. 関節結節骨皮質の描 出に関しては $15^{\circ} / 0^{\circ}, 20^{\circ} / 0^{\circ}, 25^{\circ} / 0^{\circ}, 30^{\circ} / 0^{\circ}$ の順渵 出率は低下する，関節腔の明膫度に関しては, 特に後方 関節腔の描出率は各群共に $20^{\circ} / 10^{\circ}$ が最も低い。
表13 各群における撮影法の比較

\begin{tabular}{|c|c|c|c|c|c|c|c|}
\hline A & 群 & B & 群 & $\mathrm{C}$ & 群 & D & 群 \\
\hline \multicolumn{2}{|c|}{$15^{\circ} / 0^{\circ}$} & \multicolumn{2}{|c|}{$20^{\circ} / 0^{\circ}$} & \multicolumn{2}{|c|}{$25^{\circ} / 0^{\circ}$} & \multicolumn{2}{|l|}{$30^{\circ} / 0^{\circ}$} \\
\hline & $75 \%$ & & $74 \%$ & & $43 \%$ & & $40 \%$ \\
\hline \multicolumn{2}{|c|}{$20^{\circ} / 10^{\circ}$} & \multicolumn{2}{|c|}{$20^{\circ} / 10^{\circ}$} & \multicolumn{2}{|c|}{$20^{\circ} / 10^{\circ}$} & \multicolumn{2}{|c|}{$20^{\circ} / 10^{\circ}$} \\
\hline & $71 \%$ & & $70 \%$ & & $52 \%$ & & $71 \%$ \\
\hline
\end{tabular}

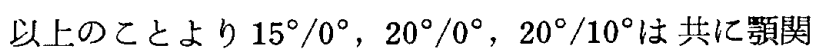
節側斜位のX線検查として適しているが，少なくとも後 方関節腔の検查には $20^{\circ} / 10^{\circ}$ は適していないといえる. Geering $(1975)^{19}{ }^{9}$ は垂直方向の角度 $25^{\circ} \sim 30^{\circ}$ は側斜位 撮影とすれば少々急峻すぎるといっているが，今回の研 究においてそれを裏づけるような結果が得られた。

側斜位撮影の入射角度を固定した場合，すなわち，規 格撮影を行った場合の踟休例における描出率は約70〜80 \%である18-20)。 Palla (1976) 20! は外来患者1664名を 対象仁してX線透視装置を用い，Camper 平面および正 中矢状平面に対するそれぞれの䫟関節の角度を求める研 究を行っている。彼の結果に上れば，Camper平面に対 する cranial angle は $0^{\circ}$ から $38^{\circ}$ まで広く分布してお り, 平均值は $20^{\circ} て ゙$, 全体の $95 \%$ は $13^{\circ}$ から $30^{\circ}$ の範囲に 分布している. また dorsal angle は正中矢状面に対し て $0^{\circ}$ から $32^{\circ}$ まで分布しており，平均は $12^{\circ}$ で, $0^{\circ}$ から $22^{\circ}$ までが全体の $97 \%$ 占めている. Yale ら $(1966)^{5)}$ は約 3000個の下顎骨の計測実験を行い，下顎頭の垂直角度は $-45^{\circ}$ から $+35^{\circ}$ まで広く分布し, 平均 $+5^{\circ}$ であり, 水平 角度は $0^{\circ}$ から $30^{\circ}$ まで分布しており, 全体の $80 \%$ \% $10^{\circ}$ か ら $20^{\circ}$ までの範囲内のものであったと述べている，ての

表14 各群における各種撮影法の描出率

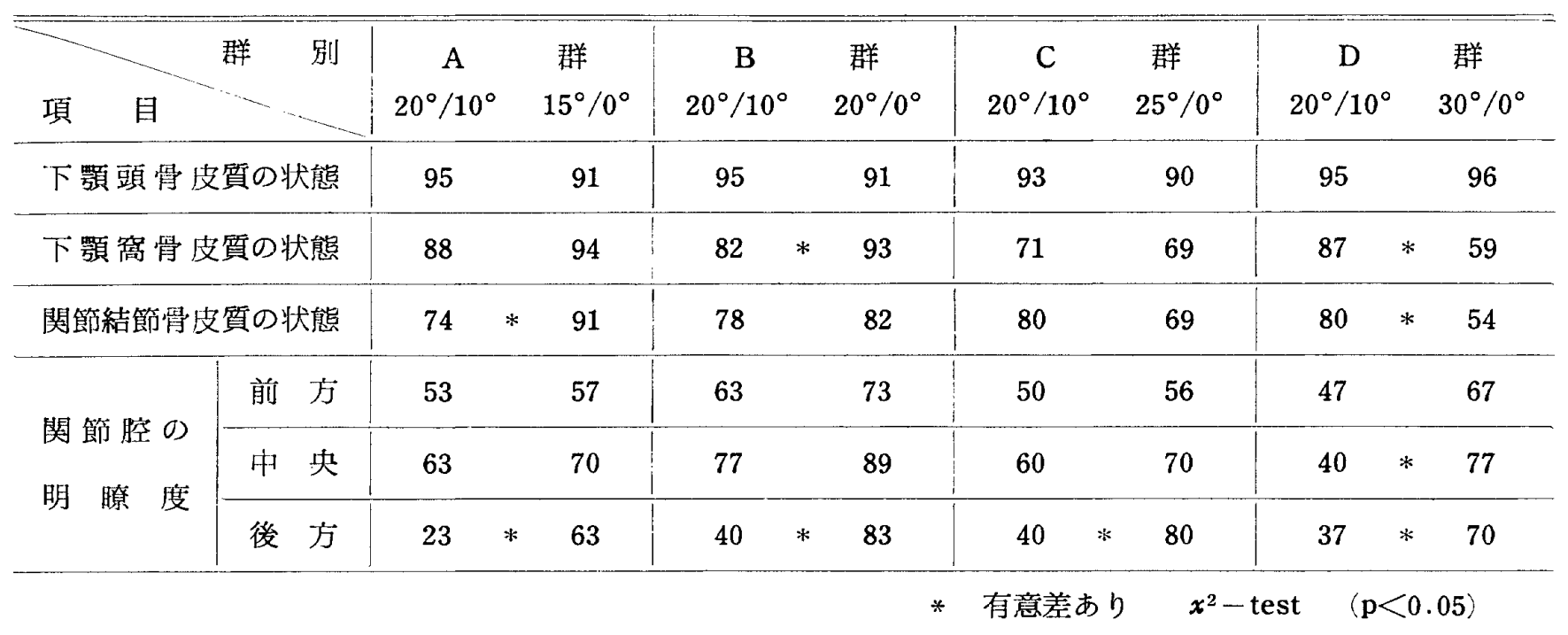


成䋶は諸蒙の解告とよく一致している11,15,21ー23'。 顎関節は解剖学的に倜体差が大きいため, 固定した角 度ではすべての症例に対して龁足な X 線像は得られな い.このような理由から Omnellら (1976)24は規格撮影 による mento-vertical view により下顎頭の水平角度 を求めている。彼等はこの個別水平角度を用いた個別側 斜位撮影と規格撮影, および断首撮影との榇断能の比較 検封を行い，個別側斜位撮影と断層撮影の組合せの方が 規格撮影と断層撮影の組合せよりも多くの病变を検出で きたと述べている。しかしながら個別側斜位撮影を行う に際しては, mento-vertical view が必要となるため患 者の被曝量が㙕加するという矢点が生ずる。一方，Egli (1969) ${ }^{16)}$ はX線透視装置を利用して，個別の顎関節に 対して最適角度を求めているが全症例の10\%において診 断に耐えるX線写真が得られなかったと迅べている．以 ヒのように個別側斜位撮影は理論的に興味ある撮影法で あるが，実際には患者の被曝量の問題や，臨休的な煩雑 さなどがあり，全く問題がないわけではない。

側斜位摄影により得られた顎関節X線写真では, 周辺 の皘造物が重複し，かなり複雑な X線像を呈する。今 回，著者は澦関節に対する錐体部，鼓室部，トルコ鞍の 床状突起などによる重なりについて調べたが，どの撮影 法においても錐体は下䝷頭と重なるという結果を得た。

Palla (1976)201の研究においても，規格化撮影および 個別撮影共に下硕頭に対する錐体縁の重なりの率の高い ことを指摘している. 中央部関節腔に関しては, 垂直方 向の角度が堌加するにしたがい錐体部との重なりは少な くなる、後方部関節膛への鼓室部の重なりは $15^{\circ} / 0^{\circ}$, $20^{\circ} / 0^{\circ}, 25^{\circ} / 0^{\circ}, 30^{\circ} / 0^{\circ}$ などは共に低い頻度を示した。 前方部関節腔と錐体部または状突起の重なりは $20^{\circ} / 0^{\circ}$ と $25^{\circ} / 0^{\circ}$ において多く起こり，15\% $10^{\circ}$ と $30^{\circ} / 0^{\circ}$ において は少ない傾向を示した。 $20^{\circ} / 10^{\circ}$ の結果と Palla (1976) $20.022^{\circ} / 10^{\circ}$ にる結果とを比較すると, 中央部関節腔 における錐体部との重なり率は, 著者の研究における方 が Palla (1976)20)の結果の約 6 倍高い数值を得た。こ のように，同じ撮影角度でもX線像が異なるということ は，いかに解剖学的な個体差が大きいかということがわ かる. $20^{\circ} / 10^{\circ}$ による方法では後方部関節腔に鼓堂部が $70 \%$ 重なり，中央部関節腔には $80 \%$ 錐体部が重なる。そ こで本撮影法は中央部から後方部にかけての関節腔のX 線検查には適していないといえる。

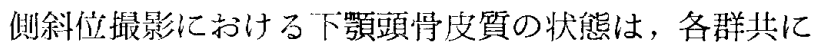
I型，すなわち正常像と判断したものが多かった。本研 岁では $15^{\circ} / 0^{\circ}$ から $30^{\circ} / 0^{\circ}$ まで種々角度を変えて撮影を衍
ったが，下買頭骨皮質の描出に関しては各撮影法共に大 差はないことが判明した。

側斜位撮影における下顎窩骨皮質の状態に関しては， $20^{\circ} / 10^{\circ}$ において全体の $82 \%$ に明瞭な骨皮質，すなわち I型が見られた。各群間の比較に扔いては，20\% けるI型の占める率は $93 \%$ と高かった，D群の $30^{\circ} / 0^{\circ}$ に おいてはI型を示す率は最も低かった。C群 $\left(25^{\circ} / 0^{\circ}\right)$ とD群 $\left(30 /{ }^{\circ} 0^{\circ}\right)$ では共にIV型を与める率は高く，次い で正型，IV型の順となる，すなわち，撮影角度が更直方 向に $25^{\circ}$ 以上なると，一下顎裔の骨皮質は全体的に不明矮 になる率は高くなるといえる，Kundert (1976)18) は $30^{\circ} / 0^{\circ}$ によ得られた顎関節のX線像のうち，不明嶛な 像を是した所を部位別に分析しているが，その中で関節 の前方部から中央部にかけての部位が不明膫なものは全 体の $5 \%$ ，前方部が不明暸なものは27\%みられたさして いる. 著者の研究ではむしろ後方部の不明膫なもの统20 $\%$ と多く，前方部および下顎窩全体が不明膫な像を献し たものは10\%であった。

側斜位撮影における関節結節骨皮質の描出には $15^{\circ} / 0^{\circ}$ が最も適した方法であり，30\% $10^{\circ}$ は最も適さない方法で ある，撮影角度が垂直方向に $25^{\circ}$ 以上なると，関簛結節 の情皮質は全体的に不明瞭な，すなわちV 型が多くみら れるようになる。

$20^{\circ} / 10^{\circ}$ の侧斜位撮影で得られた下顎頭の形態400例 を，高人 $(1961)^{4 \prime}$ の行った正常群100例と比較したとこ 万， $x^{2}=20.5>x^{2}(2,0.05)=5.99$ と有意差が認められ た。このような差を生じた主な原因として，著者の行っ た対象群はすべて男性であるのに対し，高久 (1961)4 は㽖女各々50名を対象にしたとの差によるものかもしれ ない。

左在下䫑頭の対称性は強く現われるという結果を得 た、下顎頭が左右対称性を呈するということは，顎関節 が坫調性運動を営む上において必要な要素であると考え られる。

側斜位撮影における 関節結節の形態は，圧倒的に I 型，すなわち円滑な曲線を品するものが多かった，次い で多いのは平坦型と急峻型であった，関節結節も左右対 称性を是する率が高く，左右側には有意差はみられなか った。

侧斜住撮影により得られた顎関節X線写真における関 節腔幅径の表わし方には種々あるが，その中でも下㖽頭 と下䝷窩との閒を前方, 中央, 後方部の 3 部分に分け, その部位の幅径を計测した㣮畒が多い4,15,25,26)。し かしながら，てのような計測法では各計測者による計测 
部位の違いや，同一計测者でも計測部位の再現性に問題 があるのではないかと考元られる。そこで, 関節腔幅径 の計測に際しては具体的な計測基準を設け，客钼性のあ る計測法の確立が必要となる.

下㓵窝後縁の内側半分の所には鼓室鱗裂があり，外側 半分は錐体鱗裂と錐体鼓室裂により棈成されているＸ 線'写真上では，錐体鼓室裂が下箩窩の後方部の境界とし てみられる、下顎窩から関節結節にかけての部位は円滑 な形態として現われ，下顎窩の前方部之関節結節の後方 部との境界は明確ではなく,計測上,非常に問題になる所 である：そこで著者は関節結節の最も低い点が確認しゃ すいので，その最低点を指標とした。すなわち，下靧窩 の前後径は錐体鼓室裂から関節結節の最低点までの直線 の長さと決定した：一下罰窝の前後径を示吉直線と下顎頭 が交必して生じた点を前方抢よび後方部の点とし，それ ぞれの距離を前方部および 後方部の 関節腔の幅径とし

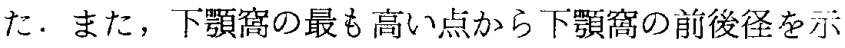
す直線に対して垂線を下し，その垂線と下顎頭とが接す る点までの距離を中奐部関節腔の幅径とした。従来から 種々な方法で下顎筒の前後径や幅径が計测されている。 Weinberg $(1970)^{27}$ は計測板を用いる方法を，また Madsen (1966) ${ }^{28)}$, Fröhlich (1967) ${ }^{29)}$, Lundberg ら $(1970)^{30)}$, 山内ら $(1976)^{31}$, 甲斐野 $(1976)^{321}$ は 計測基準点を増やすこ之を推奨している．著者の行った 方法では，下顎窩および下䫇頭の形態が著しく異なった 例においては計测しにくいことを経験した。このような 欠点を改善するためには計測点の数を増やすととが必要 となるが，あまり計測点が多くしても今度は測定䛊差を 生ずる可能性がある ${ }^{31}$ ．

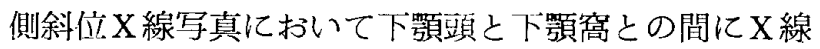
透過性腔隙が見られ，この部位は古くから joint space と呼ばれているが，乙の呼称はあくまでも放射線診断用 語である.実際にはこの部位は, 関節円板と下顎頭や関 節結節の表面を被った軟組織によって構成されている 33). 臨床的には,ての joint space は下顎窩に対する下 腼頭の位置的関係を知る重要な手がかりになる.Worth $(1963)^{34}$ によれば，乙の jojnt space が全体に拡大し た場合には，急性化膿性関節炎や血液または滲出液の睁 留が十分に疑われると述べている，逆に joint space が 狭窄している場合には，赑性融着などの原因が考元られ るとしている。また，前方部関節腔腺の搪大を是するも のとして，正常像以外に，咬合異常や関節円板の異常な ぞを挙げている.

Gerber $(1971)^{35}$ は咬頭嵌合位にお湖る下顎頭の位。
㯰は，下筫窩の中央部にあるべきだる述べている。 Weinberg $(1972)^{36)}$ は関節䊉幅径の非対称性は, 関節 円板の障害や筋スパスムスなどとのかかわりがあると主 張している. joint space は顎関節症の診断ならびにそ れらの治潦方針の磪立，おうよ゙経過観祭のための重要な 指慓となると述べている者もいる35,36)。 Mikhail ら

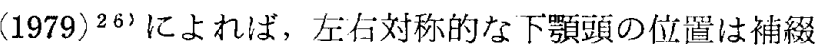
治㙩の最終目標であり，X線学的に下顎頭が後广部に位。 置しているものは前方部に位置しているものに比へ，臨 朱症状を琹する頻度が高いと述べている。

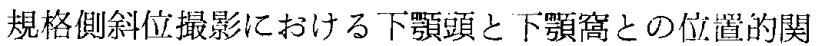
係は信用すべきではないと主張しているものもいる17， $22,30,37,381$. 側斜位摄影は入射 X線の幾何学的因素に 左右され，関節は歪んで描出されるというものもいる 14,37)。乙の上うに側斜位撮影では関節腔の幅径は実際 よりも狭く描出されるというものもいる17)，Petersson

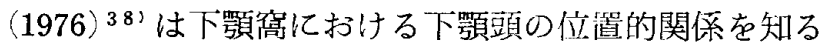
には断凰撮影が有用であると主張している。しかし，精 度の高い断㬝撮影装置がない場合には，再現性のすぐれ ている側斜位熶影により経時的に下顎頭の位置を追うこ とで十分であると还べるものもいる ${ }^{39,401 。}$

著者の研究成績では，咬頭湠合位仁扔ける下顎頭の位

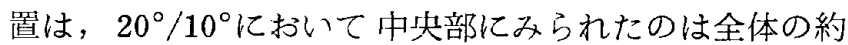
$80 \%$ であった．各群共に $20^{\circ} / 10^{\circ}$ との比較では下䫍頭の 位置に 2 割の相違がみられた。そこで Schüller's 法を 用いた場合の下顎頭の位置に扔いても踄床榇断侮して は正常な下顎頭の位置を異常と誤彰する可能性があると 考える。このような理由から顎関節疾患の䛦断に際して は病歴・臨㦿所見・咬合分析などの情報を参考にするこ とが望ましい。

表15は，顎関節に何ら症状を呈さない群であり，本学 の撮影である $20^{\circ} / 10^{\circ}$ では，下䫇頭の中央部を占める割 合は最も多く $83.5 \%$ であった. Mikhail ら (1979)26) の研究においては，下顎頭が下頭窩の中央部に位置して いたのは $36.8 \%$ と最も低い頻度を示している．てのよう

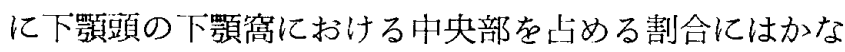
りの差がある，著者が研究対象にした年秢群とほぼ同じ 年龄群を対象沉したものに Lundberg ら $(1970)^{30} の$ 研究があるが，彼等の研究結果と著者の得た結果との間 には有意差は認められなかった。一方，Madsen (1966) ${ }^{28)}$, Palla $(1977)^{41}$, Mikhail ら (1979) ${ }^{26)}$ の結果と の間にはそれぞれ有意差がみられた。このように同じ側 斜位撮影に扔いても，一下顎頭の位置に有意差が生じる が，乙の有意差は対象群の年秢や性別などの差により生 
表15 各報告者の下顎頭の位置の比較

\begin{tabular}{c|c|c|c|r|r|r|}
\hline 報告 者 & 撮影法 & 例数 & 前方位 & 中央位 & 後方位 & $x^{2}-$ \\
test
\end{tabular}

$x^{2}=23.18$

\begin{tabular}{c|r|r|r|r|r|r}
\hline \hline 陳 & $20^{\circ} / 10^{\circ}$ & 400 & 21 & 334 & 45 & N.S. \\
Lundberg & $22^{\circ} / 0^{\circ}$ & 46 & 4 & 32 & 10 & $x^{2}=4.32$ \\
\hline \hline 陳 & $20^{\circ} / 10^{\circ}$ & 400 & 21 & 334 & 45 & $*$ \\
Madsen & $25^{\circ} / 0^{\circ}$ & 192 & 27 & 135 & 30 & $*$ \\
\hline
\end{tabular}

$x^{2}=17.24$

\begin{tabular}{c|r|r|r|r|r|r}
\hline 陳 & $20^{\circ} / 10^{\circ}$ & 400 & 21 & 334 & 45 & $*$ \\
Mikhail & $15^{\circ} / 0^{\circ}$ & 76 & 25 & 28 & 23 & $*$ \\
\hline
\end{tabular}

$\mathrm{N} . \mathrm{S}$. 有意差ない * 有意差あり $(\mathrm{p}<0.05$ )

じるかどうかは明確ではない。

関節腔幅径に関して本研究の $20^{\circ} / 10^{\circ}$ にるものと雨 斐野 $(1976)^{32}$ ' $25^{\circ} / 9^{\circ}$ により得られた結果とを比較す ると, 男子関節腔の前方, 中央, 後方部における幅径は ほぼ近似值を示していた。関節腔の幅径に関しては，X 線の入射角度が多少異っても幅径には大差は生じないと いう結果は注目に值する。本研究でも各群，すなわち， $20^{\circ} / 10^{\circ}$ と $15^{\circ} / 0^{\circ}, 20^{\circ} / 10^{\circ}$ と $20^{\circ} / 0^{\circ}, 20^{\circ} / 10^{\circ}$ と $25^{\circ} / 0^{\circ}$ $20^{\circ} / 10^{\circ}$ と $30^{\circ} / 0^{\circ}$ においては関節腔の前方部と後方部の 幅径には差はなかった。中央部の值は $20^{\circ} / 10^{\circ}$ と $25^{\circ} / 0^{\circ}$, $20^{\circ} / 10^{\circ}$ と $30^{\circ} / 0^{\circ}$ の右側の比較において 有意の差がみら れた。すなわち，下顎窩の最も高い部位と下顎頭頂部の 像は垂直方向の角度を変えることによっ一影響を受けや すいといえる。これはWeinberg (1970)27や金愁 （1981１4）の基礎的唎究とよく一致している．なお各関 節腔の幅径は各群共に左存側間には殆ど差はみられなか った。そこで関節腔の幅径が左石対称であるということ は，顎関節のX線診断に祭して重要な基準となる。

以上のことから下㓵窝における下敄頭の位置的関係を 知るためには先ず，两側の颚関節を比較し，下顎䫓が対 称的に下顎䆚の中央部に位置しているかどうかを判別し なければならない。次いで，各部位の関節腔の幅径を計 测し，左存の值を比べてみる。このような方法により， 下顎頭の位珇を主観的ならびに客観的に判断することに
より，より正確な下顎頭の位置の判定ができるものと考 える。

II ・眼窩撮影について

この方法は下䪽頭の正面像をよく描出することがで き，側斜位撮影の補助的手段として區床的にも用いられ ている，撮影に際してのX線の入射角度には種々ある が，一般に前上方から $20^{\circ} \sim 30^{\circ}$, さらに検側に2 $0^{\circ}$ 偏心 してX線を入射する方法が多く用いられている. 眼裔撮 影の呼称名は種々あり, ventro-dorsaler projektion des kiefergelenkes ${ }^{42}$ ', orbito-ramus view ${ }^{43}$ ', oblique-orbital projection ${ }^{4}$ ', trans-orbital view ${ }^{45}$ ', transmaxillary projection ${ }^{46}$, , transantrale kiefergelenkprojektion $^{12}$ 'なよ゙と称されている。眼窩撮影で は下顎頭の正面像だけではなく, 関節結節の正面像も得 られるので下顎頭や関節結節の形態および質的变化の有 無などの検索に適したX線検查法といえる。しかしなが ら，本撮影法に扔いても技術的な問題が多く，乳様突起 や煩骨突起と下嚬頭とが重なりやすく読影が困難な場合 が多い，著者の結舆では乳様突起と下頡頭との重なりが 最も多く $(71.7 \%)$ ，媔骨突起との重なりは比較的少な かった $(27 \%)$. 竹之下 $(1979)^{47)}$ は関節絬節と下䫑頭 の重なりは全体の $41 \%$ \%台めていたとしている，著者の

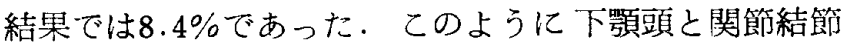
との重なりに差が比じる主な原因として対象群の違いが 思われる．竹之下 $(1979)^{47}$ が研究対象とした群は開口 障害のあるものが多く，そのため，下頨頭と関節結節と の重なりが多く生じるものと思われる、また, 彼の正常 群に扔ける結果でも，下顎頭と関節結節は比較的高率で 重複しているが，乙れは撮影法の違いや対象群の年粭分 布の違いによるものと考えられる.

下颚頭の骨構造については下顎頭骨皮質，骨梁の排 列，骨髄腔などについて調べた。正常群における骨皮質 の厚さは，下頭の内外僛ではほぼ同じであり，頂部では 内外側に比へ薄いことが判明した。骨梁は関節面に対し

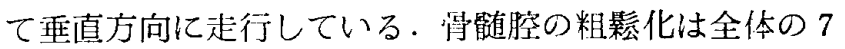
\%にみられ，中央部または外側部において観察された。

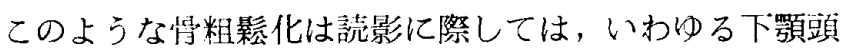
の pseudocyst formation との鑑别が必要となる. 関 節結節の悄皮質は均一な愿さで，しかも全体に明膫に認 められる場合が多かった。

下䫎頭の形態については, convex, round, flat, angled の形を哇したものの順に多かった. Yale ら $(1966)^{5)}$ による研究でも, convex, flat, angled, roundの順に多く，著者の得た結果とほぼ同様の結果を 
示している. 下顎頭の左右対称性については，対称性を 示したものは全体の $81.4 \%$ を占めている。今含回の研究の 対象群はすべて正常例であり，しかも，年齿的にも顎関 節は成長しきったものである。そのためか退行性病変に よる形態の変化や生理的な骨組織の再構築による変化は 認められなかった。

関節結節の形驡を 3 つの型に分類したが，その中で 平坦型が最も多かった，不規則型と彎曲型はほぼ同じ頻 度を示した. Steinhardt $(1963)^{481}$ は頻関節の形態は閉 鎖型（Geschlossene Gelenkform）と開放型（Offenen Gelenkform）に分類できると述へている．閉鎖型と は，関節結節の形態が図20に示すように䅧曲型を呈した ものであり，側斜位撮影で関節結節の外側部と内側部が 重複した像として現われるものである．開放型とは，渚 者の分類の平坦型に似たものであり，側斜位像で単純な 関節結節として描出されるものである。著者は眼窩法で 得られた関節結節の形態を分類し，それぞれの側斜位撮 影 $\left(20^{\circ} / 10^{\circ}\right)$ で得られた関節結節のうち，骨皮質が全 体的明膫なものとの相関を求めるために, 平坦型（A $\mathrm{F})$, 彎曲型 (A C ), 不規則型 (A I ) の3 型との組合 せを作り分析してみた。 3 群間には有意差はみられなか ったが平坦型（A F）の組合せが33.8\%を占め, 彎曲型 (A C ) $25.7 \%$ と不規則型（A I ）の組合せが $22.5 \%$ を 占めている.すなわち, Steinhardt $\left.(1963)^{48}\right)^{8}$ が述べて いるように関節結節の形態と側斜位像との相関関係は認
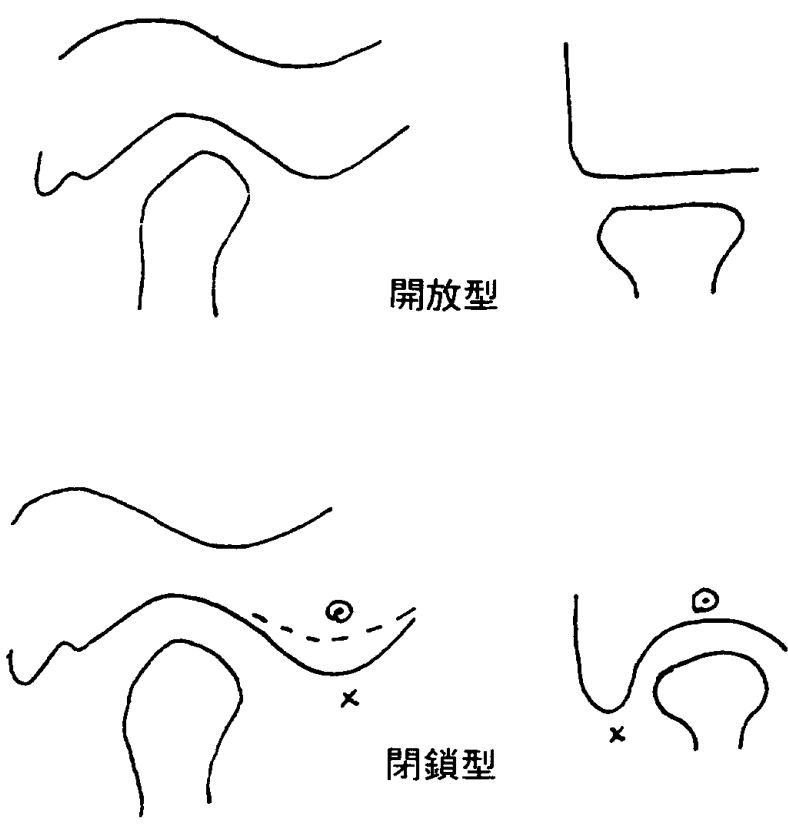

図20 側斜位撮影と眼窩撮影における関節結節の形 態の比較 (Steinhardt (1963 ${ }^{48}{ }^{2}$ から引用)
めら机なかった。

下嚬頭頂部に扔ける concavity の出現淬は $6.2 \%$ であ った. Peterssonら $(1975)^{6}{ }^{\prime}$ は 100 例の頸関節疾患を有 する患者の中で18例の concavity を認めている。この ように concavity の出現は䋶関節疾患を有するものに おいて比較的多く出現するようである. concavity の存 在部位は, 著者の研究に㧈いては下顎頭の中央部におい

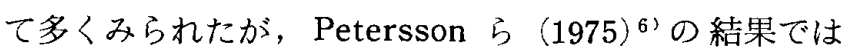
中央部と外側部にほぼ同し頻度で出現している。下䫟頭 の concavity に関して Moffett (1974)11)は normal variation であると考えており，顎運動に忘じて生じた remodelingであるとも考えている. Worth $(1974)^{49)}$ は concavity “central depression”之称している が, normal variation とみなしているのは Petersson ら $\left.(1975)^{6}\right)$ と同じである. 桸な場合にはこのdepression は下嶺頭を 2 分し, cleft 在生じ将来異常を生じるかも しれないと述へている．著者も下顎頭の concavityに 関してはPetersson ら $(1975)^{62}$ と同様に normal variationであると考えている.

下靧頭におけるその他の所見として， osteophyte を 6 例に諗めた. Ericson ら $(1968)^{50}{ }^{\prime}$ は80名の顯関節に 何ら症状はない患者において osteophyte 童 $28.8 \%$ 認め ている. Petersson ら $(1975)^{61}$ は顎関節異常群におい て全検查件数の $71 \%$ に osteophyte を検出している. osteophyte は, 顎関節の最も圧力かかる部位のarticular fibrocartilage が線維性痤縮（fibrillation）を起こし， その末梢部が過形成することによって辺緣部（lip） 在生 じるのではないかと考えられている49)。乙のlipは徐々 に大きくなり骨化し, osteophyte となり，特徵的なX 線不透過像を呈する.ての osteophyte は顎関節の退行 性病変と見なされ，側斜位撮影では，下顎頭の前方によ くみら机る ${ }^{49}$ 。 また，平坦化した関節結節の前方部に も出現する511. Worth $(1974)^{491}$ によれば osteophyte は疼痛などの症状を呈さないが，正常な顎運動に支障を 来たし，いわゆる fibrous ankylosisになることがある と示唆している。

\section{結 論}

顎関節およびその周辺纪何ら臨床症状を伴わない成人 男子 200 名の頜関節を対象にして, 眼耳平面之正中矢状 面に対しそれぞれ $20^{\circ}$ と $10^{\circ}$ の方法と Schüller's 法を応 用し得られ 800 枚のX線写真を分析し, 各種撮影法を評 価した。また，腿窩・下顎枝撮影法により得られた 226 枚のX線写真についても詳細に分析した。得られた結果 
は次のとおりである。

1）顎関節側斜位撮影法における下顎頭の位置は，一下 顎窩中央部にある場合が多い $(75 \%) \cdot 20^{\circ} / 10^{\circ}$ による撮 影では下顎頚が快央部に位置したものは全体の約 $84 \%$ で あった。一下顎頭の位犆を前方部と後方部とで比較した場 命，後方部におけるものは前方部におけるものの2 倍多 くみられた。

2）顎関節側斜愔撮影法の中では，下頡窩，および関節 結節の舆皮質の検索と関節腔の锶祭には $20^{\circ} / 0^{\circ}$ と $15^{\circ} / 0^{\circ}$ が最も適しており，次いで $20^{\circ} / 10^{\circ}$ の䫍となる。 $25^{\circ} / 0^{\circ}$ 亡 $30^{\circ} / 0^{\circ}$ は少なくとも骨没質や関節腔の検索には適した $\mathrm{X}$ 線検查法とはいえない。

3）顎関節側斜位撮影法で錐体部，鼓空部およびトル コ鞍の床状突起などによる関節部への重なりは30\% $/ 0^{\circ}$ 以 外の方法では避けることは不可能である。

4) 顎関節側斜位撮影法では下顎頭の形態は左在対称 的な形態を示すものが多かった。形態としては人示指䫓 状を示したものが最も多く，次いで尖鋭頭状，塊状，一 の他の順となる。

5）顎関節側斜位撮影法における関節結節の形態は， 円滑型が最も多く, 次いで平坦型, 急峪型の順となる. 関節結節も左右対称的な形態死示す場合が多い。

6）下顎窝の前後湰は左側よりも右側の方が大きく， 高さは右側の方が大きい。 $20^{\circ} / 10^{\circ}$ における前後径の平

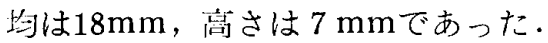

7) 関節腔の幅径に関して， $20^{\circ} / 10^{\circ}$ では前方部は $6.0 \mathrm{~mm}$, 中央部は $3.6 \mathrm{~mm}$, 後方部は $3.5 \mathrm{~mm}$ であった. 前方部, 中央部, 後方部における関節腔幅径の此は約 $1.7: 1.0: 1.0$ となる.

8) 眼㸗・下嚬枝撮影法では, 乳様突起, 煩骨突起お よび関節結節などによる下顎頭への重なりは詤影に支障 を来たすほどのものではない。

9) 眼窩・㖽枝撮影法に衫ける下顎頭の 形態は， convex が最も多く $(61.5 \%)$, 次いで round $(19.9 \%)$, flat $(13.2 \%)$ ，その他 $(3.6 \%)$, angled $(1.8 \%)$ の順 となる、下顎頭の形態は左右対称的形態を是する場合が 多かった。

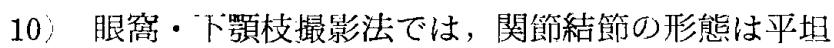
型を六すものが最も多く，全体の45\%を占如ていた。次 いで禁曲型 $(27.4 \%)$ ，不規則型 $(27 \%)$ の順となる. 関節結節寻左右対称的形態を呈する場合が多い。

稿を終るにあたり，本研究に際して終始御懇切なる御 指導ならび御校閲を賜った恩師大庭健教授に深甚なる荍 意と感謝の意を表しますままた央験の御援助をいただい た斗央研究䇪小川泰大講師に蚸心より感謝の意を表しま す，あわせて，本研究に御協力下さった歯科放射線学教 定の皆様に感謝致します。

\section{引用文献}

1）陳 昭榮・大庭 健・小川泰夫・花野正純・三吉聖一朗・清水国男：本学附属病院における雪科 X線検查の 推移. 九州霖会誌 $32: 857--862,1979$.

2) 大庭 健 - 森進一郎 - 畠山 篤・進野政則・小川泰夫 ·太田 正・柏木茂昌・平田周三・石部正人：顎関節

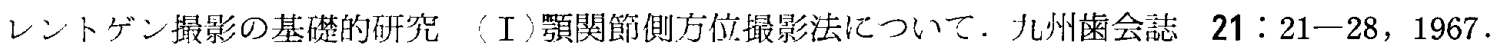

3）平田周三：顎関節のX線学的研究一顎関節側斜位摆影法により得られたX線像の分析一。州䨑会誌 32 ： $374-392,1978$.

4 ) 高久 暹: 正常ならびに病的顎関節のX線学的研究. 月曰外流 7:203-219, 1961 .

5 Yale, S.H., Allison, B.D. and Hauptfuehrer, J.D. : An epidemiological assessment of mandibular condyle morphology. Oral Surg. $21: 169-177,1966$.

6 Petersson, A. and Nanthaviroj, S. : Radiography of the temporomandibular joint utilizing the transmaxillary projection. Dentomaxillofac. Radiol. 4:76-83, 1975.

7) Hansson, L.G. and Petersson, A. : Radiography of the temporomandibular joint using the transpharyngeal projection : A comparison study of information obtained with different radiographic techniques. Dentomaxillofac. Radiol. $7: 69-78,1978$.

8 Lewis, G.R. : Temporomandibular joint radiographic technics: Comparison and evaluation of results. Dent. Radiogr. Photogr. 37:8-20, 1964. 
9) Carlsson, G.F., Lundberg, M., Öberg, T. and Welander, U. : The temporomandibular joint : A comparative anatomic and radiologic study. Odonto. Revy $19: 171-185,1968$.

10) Bean, L.R., Omnell, K. А. and öberg, T. : Comparison between radiologic observations and macroscopic tissue changes in temporomandibular joint. Dentomaxillofac. Radiol. $6: 90-106$, 1977 .

11) Moffett, B. C. : The temporomandibular joint. In : Complete denture prosthodontics (ed. by Sharry, J. J.). 3rd ed. New York, McGraw-Hill, 1974, 56-104.

12) Tveito, L. : Die transantrale Kiefergelenkprojektion-ein Ergänzung der transversalen Projektionen. Dtsch. Zahnärztl. Z. $32: 583--587,1977$.

13）竹之下康治：頭部 $X$ 線規格写真による成人下買頭の観祭— Transcranio-lateral oblique projection の検 㰸一。 日曰处誌 $24: 1-7,1978$.

14）金森敏和：顎関節 $X$ 線㝍真の規格化に関与る研究。第 1 報。単純撮影法について. 補緅誌 $25: 80$ 一 1981 .

15) Craddock, F.W. : Radiography of the temporomandibular joint. J. Dent. Res. 32:302-321, 1953.

16) Egli, U. : Das Röntgenbild in der Kiefergelenk-bezüglichen Okklusionsdiagnostik. Schweiz. Mschr. Zahnheilk. $79: 1220-1246,1969$.

17) Treito, L. : Beurteilung der Gelenkspaltbreite. Dtsch, Zahnärztl. Z. 29:550-553, 1974.

18) Kundert, M. : Zum Aussagewert des Kiefergelenkröntgenbildes nach Schüller für die gelenkbezogene Okklusionsdiagnostik. Schweiz. Mschr. Zahnheilk. 86:393-412, 1976.

19) Geering, A. : Beurteilung und Interpretation von Kiefergelenkröntgenbildern. Schweiz. Mschr. Zahnheilk. $85: 385-398,1975$.

20) Palla, S. : Eine Mittelwertprojektion für Kiefergelenkaufnahmen in schräglateraler Projektion. Schweiz. Mschr. Zahnheilk. 86:1207-1226, 1976.

21) Amer, A. : Approach to surgical diagnosis of the temporomandibular articulation through basic studies of the normal. J. Am. Dent. Assoc. 45:668-688, 1952.

22) Berry, D. C. : The relationship between some anatomical features of the human mandibular condyle and its appearance on radiographs. Arch. Oral Biol. 2:203-208, 1960.

23) Taylor, R. C., Ware, W. H., Fowler, D. and Kobayashi, J. : A study of temporomandibular joint morphology and its relationship to the dentition. Oral Surg. $33: 1002-1013,1972$.

24) Omnell, K. $\AA$. and Petersson, A. : Radiography of the temporomandibular joint utiilzing oblique lateral transcranial projections. Odont. Revy $27: 77-92,1976$.

25) Kleinork, M. und Kobylecka, E. : Typisierung von Röntgenbefunden der Kiefergelenke bei Patienten mit funktionell bedingten Myoarthropathien. Dtsch. Zahnärztl. Z. 33:154-157, 1978.

26) Mikhail, M. G. and Rosen, H. : The validity of temporomandibular joint radiographs using the head positioner. J. Prosthet. Dent. 42:441-446, 1979.

27) Weinberg, L. A. : An evaluation of duplicability of temporomandibular joint radiographs. $J$. Prosthet. Dent. $24: 512-541,1970$.

28) Madsen, B. : Normal variations in anatomy, condylar movements, and arthrosis frequency of the temporomandibular joints. Acta. Radiol. Diagn. 4:273-288, 1966.

29) Fröhlich, F. : Zur Reproduzierbarkeit von kiefergelenkröntgenbildern. Schweiz. Mschr. Zahnheilk. $77: 611-630,1967$.

30) Lundberg, M. and Welander, U. : The articular cavity in the temporomandibular joint: A 
comparison between the oblique-lateral and the tomographic image. Medicamundi 15:2729,1970 .

31）山内哲義・中村公雄・下総高次・西原平八・淵端 舌：䝷関節側方 X線規格写真による顆頭位の分析方法に つて. 補経誌 $20: 193$-206, 1976.

32）甲斐野弘：側斜方向X線規格像による正常青年有柬顎者と総義柬装着者とにおける顎関節腔の幅と下顎頭移 動量の比較. 日大料学 $50: 698-706,1976$.

33) Omnell, K. А. : Radiology of the temporomandibular joint. In : Current advances in oral surgery (ed. by Irby, W.B.). Vol III. St. Louis, Mosby, 1980, 196-226.

34) Worth, H. M. : Principles and practice of oral radiologic interpretation. Chicago, Year Book Medical Publishers Inc., 1963, 695.

35) Gerber, A. : Kiefergelenk und Zahnokklusion. Dtsch. Zahnärztl. Z. $26: 119-141$, 1971.

36) Weinberg, L. A. : Correlation of temporomandibular dysfunction with radiographic findings. $J$. Prosthet. Dent. $28: 519-539,1972$.

37) Berry, D.C. and Chick, A.O.: Temporomandibular joint: Interpretation of radiographs. Dent. Pract. $7: 18-24,1956$.

38) Petersson, A. : Radiography of the temporomandibular joint: A comparison of information obtained from different radiographic techniques. Malmö, University of Lund, 1976, 1-24.

39) Petersson, A. : X 線検査の果す役割, 靧関節を考える。レントゲン・外科・補緅の立場から・大阪大学 棶学部同空会誌 $2-9,1980$.

40）上村修三郎：顎関節を考える。レントゲンの立場から．大阪大学菌学部同瑤会誌 $10-22,1980$.

41) Palla, S. : Eine Studie über die Kondylenposition im Röntgenbild. Schweiz. Mschr. Zahnheilk. $87: 304-309,1977$.

42) Zimmer, E.A. : Zur Darstellung des normalen Kiefergelenkes im Röntgenbilde. Radiol. Clin. (Basel) $9: 170-182,1940$.

43) Grant, R. and Lanting, H. : An improved technic for roentgenographic examination of the temporomandibular joint and condyle. J. Oral Surg. 11:95-101, 1953.

44) McCabe, J. B., Keller, S. E. and Moffett, B.C.: A new radiographic technic for diagnosing temporomandibular joint disorders. J.Dent. Res. $38: 663,1959$.

45) Smith, N. J. D. and Harris, M. : Radiology of the temporomandibular joint and condylar head. Brit. Dent. J. $129: 361-368,1970$.

46) Bean, L. R., Petersson, A. and Svensson, A. : The transmaxillary projection in temporomandibular joint radiography. Dentomaxillofac. Radiol. 4:13-18, 1975.

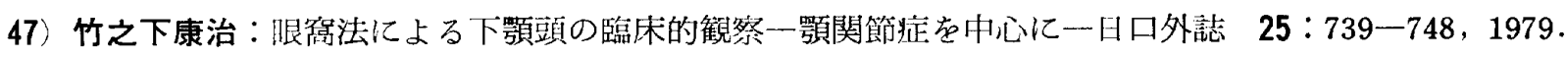

48) Steinhardt, G. : Pathologische Veränderungen der Kiefergelenke. In : Handbuch der Medizinischen Radiologie (eds. by Olsson, O., Strnad, F., Vieten, H. and Zuppinger, A.). Vol.VII/2 Berlin, Springer-Verlag, 1963, 367.

49) Worth, H.M. : The role of radiological interpretation in disease of the temporomandibular joint. In : Temporomandibular joint-function and dysfunction $\Pi$ (eds.by Melcher, A.H. and Zarb, G.A. Copenhagen, Munksgaard, 1974, 3-50.

50) Ericson, S. and Lundberg, M. : Structrural changes in the finger, Wrist and temporomandibular joints : A comparative radiologic study. Acta Odontol. Scand. $26: 111-126,1968$.

51) Worth, H. M. : Radiology of the temporpmandibular joint, In : Temporomandibular joint function and dysfunction (eds. by Zarb, G.A. and Carlsson, G. E.). Copenhagen, Munksgaard, 1979, 349 . 